\title{
A-Kinase Anchoring Protein-Calcineurin Signaling in Long-Term Depression of GABAergic Synapses
}

\author{
Matthieu Dacher, Shawn Gouty, Steven Dash, Brian M. Cox, and Fereshteh S. Nugent \\ Department of Pharmacology, Uniformed Services University of the Health Sciences, Bethesda, Maryland 20814
}

\begin{abstract}
The postsynaptic scaffolding A-kinase anchoring protein 79/150 (AKAP79/150) signaling complex regulates excitatory synaptic transmission and strength through tethering protein kinase A (PKA), PKC, and calcineurin (CaN) to the postsynaptic densities of neurons (Sanderson and Dell'Acqua, 2011), but its role in inhibitory synaptic transmission and plasticity is unknown. Using immunofluorescence and whole-cell patch-clamp recording in rat midbrain slices, we show that activation of postsynaptic $\mathrm{D}_{2}$-like family of dopamine (DA) receptor in the ventral tegmental area (VTA) induces long-term depression (LTD) of GABAergic synapses on DA neurons through an inositol triphosphate receptor-mediated local rise in postsynaptic $\mathrm{Ca}^{2+}$ and CaN activation accompanied by PKA inhibition, which requires AKAP150 as a bridging signaling molecule. Our data also illuminate a requirement for a clathrin-mediated internalization of $\mathrm{GABA}_{\mathrm{A}}$ receptors in expression of $\mathrm{LTD}_{\mathrm{GABA}}$. Moreover, disruption of AKAP-PKA anchoring does not affect glutamatergic synapses onto $\mathrm{DA}$ neurons, suggesting that the PKA-AKAP-CaN complex is uniquely situated at $\mathrm{GABA}_{\mathrm{A}}$ receptor synapses in VTA DA neurons to regulate plasticity associated with $\mathrm{GABA}_{\mathrm{A}}$ receptors. Drug-induced modulation of GABAergic plasticity in the VTA through such novel signaling mechanisms has the potential to persistently alter the output of individual DA neurons and of the VTA, which may contribute to the reinforcing or addictive properties of drugs of abuse.
\end{abstract}

\section{Introduction}

$\mathrm{GABA}_{\mathrm{A}}$ receptor $\left(\mathrm{GABA}_{\mathrm{A}} \mathrm{R}\right)$-mediated GABAergic transmission provides synaptic inhibition at the vast majority of inhibitory synapses in the brain in which it regulates the excitability and function of the individual neurons as well as neural networks. Mounting evidence suggests that synaptic plasticity at GABAergic synapses plays an important role in normal brain functions, such as experience-dependent learning, but also in pathological conditions, including drug addiction (Dacher and Nugent, 2011a). As with plasticity at excitatory synapses, both long-term potentiation (LTP) and long-term depression (LTD) occur at GABAergic synapses in different areas of the brain, including the ventral tegmental area (VTA) (Nugent and Kauer, 2008). Dopamine (DA) release from VTA DA neurons in limbic forebrain areas, such as the nucleus accumbens (NAc), controls rewardmotivated learning. Indeed, direct optogenetic activation of VTA DA neurons is reinforcing (Adamantidis et al., 2011), and all major drugs of abuse mediate their reinforcing effects by increasing DA release from the VTA (Di Chiara and Imperato, 1988).

Received April 27, 2012; revised Dec. 11, 2012; accepted Dec. 16, 2012.

Author contributions: M.D., S.G., B.M.C., and F.S.N. designed research; M.D., S.G., S.D., and F.S.N. performed research; S.G. and B.M.C. contributed unpublished reagents/analytic tools; M.D., S.G., and F.S.N. analyzed data; M.D., S.G., B.M.C., and F.S.N. wrote the paper.

This work was supported by a Whitehall Foundation grant-in-aid (F.S.N.) and a Department of Defense intramural grant from the Uniformed Services University. We are grateful to Drs. David Lovinger, Stefano Vicini, and Thomas Cote for their critical discussions of previous versions of this manuscript.

The authors declare no competing financial interests.

Correspondence should be addressed to Fereshteh Nugent, Department of Pharmacology, Uniformed Services University of the Health Sciences, 4301 Jones Bridge Road, Bethesda, MD 20814. E-mail: fereshteh.nugent@usuhs.edu.

DOI:10.1523/JNEUROSCI.2037-12.2013

Copyright $\odot 2013$ the authors $\quad 0270-6474 / 13 / 322650-11 \$ 15.00 / 0$
The strength of both glutamatergic and GABAergic synapses on VTA DA neurons are shown to be altered in response to drugs of abuse, and this drug-induced plasticity is thought to underlie long-lasting behavioral changes associated with drug experience (Lüscher and Malenka, 2011), yet the precise molecular mechanisms by which addictive drugs alter synaptic plasticity remain unclear.

Recently, we described a novel form of activity-induced GABAergic plasticity in VTA DA neurons $\left(\mathrm{LTD}_{\mathrm{GABA}}\right)$ that was absent in slices from rats that received a single in vivo exposure to morphine (Dacher and Nugent, 2011b). Similarly, LTP at the same GABAergic synapses in VTA DA neurons $\left(\mathrm{LTP}_{\mathrm{GABA}}\right)$ was blocked after a single in vivo morphine treatment (Nugent et al., 2007). These data suggest that GABAergic plasticity in the VTA is an important target for opiates and maybe other addictive drugs in modulating the excitability of DA neurons. To address the question of how drugs of abuse can trigger or modulate GABAergic plasticity at synapses, it is essential to identify the underlying mechanisms that mediate this plasticity. In the present study, we demonstrate a novel role for A-kinase anchoring protein 150 (AKAP150)-dependent signaling in mediating $\mathrm{LTD}_{\mathrm{GABA}}$. The AKAP family of scaffold proteins plays an important role in localization of specific kinases [e.g., protein kinases A (PKA) and C $(\mathrm{PKC})]$ and phosphatases [e.g., calcineurin $(\mathrm{CaN})$ ] to the synapses that control NMDA, AMPA, and $\mathrm{GABA}_{\mathrm{A}}$ receptor trafficking and function (Klauck et al., 1996; Luscher et al., 2011; Sanderson and Dell'Acqua, 2011). Moreover, disruption of AKAP150-dependent signaling in the NAc has been found to impair the reinstatement of cocaine-seeking behavior through modulation of AMPA receptor (AMPAR) trafficking, suggesting the critical role of AKAP proteins in susceptibility to relapse 
(Reissner et al., 2011), although the role of AKAP signaling in synaptic transmission and plasticity in the VTA is unexplored. Here, we provide the first evidence for the selective regulation of $\mathrm{GABA}_{\mathrm{A}} \mathrm{R}$ trafficking-mediated GABAergic plasticity by endogenous $D A$ and $D_{2}$ receptors (for simplicity, the $D_{2}$-like family of DA receptors will be identified as $\mathrm{D}_{2}$ Rs throughout) that requires an inhibitory G-protein-PKA-inositol triphosphate receptor $\left(\mathrm{IP}_{3} \mathrm{R}\right)-\mathrm{Ca}^{2+}$ CaN-AKAP signaling mechanism.

\section{Materials and Methods}

Slice preparation for electrophysiology. For electrophysiological studies, we used 14- to 22-d-old Sprague Dawley (male and female) rats. Housing and care were the same as described previously (Dacher and Nugent, 2011b). Midbrain horizontal slices $(250 \mu \mathrm{m})$ were cut and incubated at least $1 \mathrm{~h}$ at $34^{\circ} \mathrm{C}$ before recordings in artificial CSF (ACSF) containing the following (in mM): $126 \mathrm{NaCl}, 21.4 \mathrm{NaHCO}_{3}, 2.5 \mathrm{KCl}, 1.2 \mathrm{NaH}_{2} \mathrm{PO}_{4}, 2.4$ $\mathrm{CaCl}_{2}, 1.0 \mathrm{MgSO}_{4}, 11.1$ glucose, and 0.4 ascorbic acid (saturated with $95 \% \mathrm{O}_{2} / 5 \% \mathrm{CO}_{2}$ ). Slices were then transferred to a recording chamber and submerged in warm $\left(28^{\circ} \mathrm{C}\right)$ ascorbic acid-free ACSF.

Electrophysiology. Whole-cell recordings were performed using a patch amplifier (Multiclamp 700B) under infrared differential interference contrast microscopy. Data acquisition and analysis were performed using DigiData 1440A and pClamp 10 (Molecular Devices). GABA $\mathrm{A}_{\mathrm{A}} \mathrm{R}$-mediated IPSCs were isolated and recorded as described previously (Dacher and $\mathrm{Nu}-$ gent, 2011b) in ACSF containing 6,7-dinitroquinoxaline-2,3-dione (10 $\mu \mathrm{M})$, and strychnine $(1 \mu \mathrm{M})$. In some experiments, AMPAR-mediated EPSCs were isolated and recorded using ACSF containing picrotoxin $(100 \mu \mathrm{M})$. The patch pipettes were filled with the following (in $\mathrm{mM}$ ): $125 \mathrm{KCl}, 2.8 \mathrm{NaCl}, 2$ $\mathrm{MgCl}_{2}, 2$ ATP-Na ${ }^{+}, 0.3$ GTP-Na ${ }^{+}, 0.6$ EGTA, and 10 HEPES, $\mathrm{pH}$ adjusted to 7.28 with $\mathrm{KOH}$ (osmolarity adjusted to $275-280 \mathrm{mOsm}$ ). A subset of experiments with quinpirole used an internal solution in which $125 \mathrm{~mm} \mathrm{CsCl}$ was substituted for $\mathrm{KCl}$, and $\mathrm{CsOH}$ was used to adjust the $\mathrm{pH}$. Cells were voltage clamped at $-70 /-80 \mathrm{mV}$, except during the LTD protocol. The cell input resistance and series resistance were monitored through the experiment, and, if these values changed by $>10 \%$, data were not included. Paired $\mathrm{GABA}_{\mathrm{A}}$ IPSCs or AMPAR-mediated EPSCs were stimulated using a bipolar stainless steel stimulating electrode placed $200-500 \mathrm{~mm}$ rostral to the recording site in the VTA at $0.1 \mathrm{~Hz}(100 \mu \mathrm{s})$. The stimulation intensity was adjusted so that the amplitude of synaptic responses ranged from -200 to $-800 \mathrm{pA}$. LTD was induced using low-frequency stimulation (LFS) of $1 \mathrm{~Hz}$ for $6 \mathrm{~min}$ while cells were voltage clamped at $-40 \mathrm{mV}$ (for simplicity, in all figures, "pairing" represents the protocol used for LTD induction). The appearance of an hyperpolarization-activated current $\left(I_{\mathrm{h}}\right)(\geq 50 \mathrm{pA})$ in response to stepping cells from -50 to $-100 \mathrm{mV}$ was used to identify VTA DA neurons.

Drug treatment. Drugs were present in ACSF perfusing slices in the recording chamber at the indicated concentrations for at least $15 \mathrm{~min}$ before the LTD protocol. Interleaved control experiments were performed with experiments in which drugs were bath applied. For BAPTA experiments, the intra-pipette solution contained $80-90 \mathrm{~mm} \mathrm{KCl}$ and 20-30 mM BAPTA, with no added EGTA. Slices were preincubated in $1 \mu \mathrm{m}$ cyclosporin $\mathrm{A}$ for $\geq 2$ $\mathrm{h}$ before being transferred into the recording chamber. The drug was also present throughout the experiments. In a subset of experiments, cyclosporine $\mathrm{A}(1 \mu \mathrm{M})$ was used in the intracellular recording pipette. FK506 [ $3 S, 4 R$, $5 S, 8 R, 9 E, 12 S, 14 S, 15 R, 16 S, 18 R, 19 R, 26 a S)-5,6,8,11,12,13,14,15,16,17,18,19$, 24,25,26,26a-hexadecahydro-5,19-dihydroxy-3-[(1E)-2-[(1R,3R,4R)-4hydroxy-3-methoxycyclohexyl]-1-methylethenyl]-14,16-dimethoxy-4,10, 12,18-tetramethyl-8-(2-propen-1-yl)-15,19-epoxy-3H-pyrido[2,1-c][1, 4] oxaazacyclotricosine- $1,7,20,21(4 H, 23 H)$ tetrone] was dissolved in DMSO and diluted to the final concentration in the intracellular recording pipette. All the drugs were purchased from Sigma, Tocris Bioscience, or Calbiochem. $\mathrm{Ht} 31$ and Ht31p (control peptide) were obtained from Promega. Pitstop2 and its control peptide were purchased from Abcam.

Data analyses. Values are presented as means \pm SEM. Statistical significance was determined using repeated-measures ANOVA with significance level of $p<0.05$. Levels of LTD are reported as averaged IPSC amplitudes for $5 \mathrm{~min}$ just before LTD induction compared with averaged IPSC amplitudes during the $5 \mathrm{~min}$ period from 20 to $25 \mathrm{~min}$ after the protocol. Levels of quinpirole-/ $\mathrm{PKI}_{(6-22)}$-/Ht31-induced depression are reported as averaged IPSC amplitudes for 5 min just before the emergence of drug-induced synaptic depression compared with averaged IPSC amplitudes during the last $5 \mathrm{~min}$ period of the peak response. The average time point of drug-induced rundown represents averaged durations after the initiation of the whole-cell configuration and the emergence of drug-induced depression, calculated in each experiment. Paired-pulse ratios (PPRs) (50 ms interstimulus interval) were measured over 5 min epochs of 30 IPSCs as described previously (Nugent et al., 2007).

Immunohistochemistry and image analyses. Male adult Sprague Dawley rats weighing $300 \mathrm{~g}$ (Taconic Farms) were housed individually in a plastic cage and kept on a $12 \mathrm{~h} \mathrm{light/dark} \mathrm{cycle.} \mathrm{Food} \mathrm{and} \mathrm{water} \mathrm{were} \mathrm{provided} \mathrm{ad}$ libitum. Rats were anesthetized with an intraperitoneal injection containing ketamine $(85 \mathrm{mg} / \mathrm{kg})$ and xylazine $(10 \mathrm{mg} / \mathrm{kg})$ and perfused through the aorta with $300 \mathrm{ml}$ of heparinized $1 \times$ PBS, followed by $250 \mathrm{ml}$ of $4 \%$ paraformaldehyde (PFA) (USB). The brains were dissected and placed in $4 \%$ PFA for $24 \mathrm{~h}$ and then cryoprotected by submersion in $20 \%$ sucrose for $3 \mathrm{~d}$, frozen on dry ice, and stored at $-70^{\circ} \mathrm{C}$ until sectioned. Sections of the VTA were cut using a cryostat (Leica CM1900) and mounted on slides. Serial coronal sections $(20 \mu \mathrm{m})$ of the midbrain containing the VTA [from -4.92 to $-6.72 \mathrm{~mm}$ caudal to bregma (Paxinos and Watson, 2007)]) were fixed in 4\% PFA for 5 min, washed in $1 \times$ PBS, and then blocked in $10 \%$ normal horse serum (NHS) containing $0.3 \%$ Triton $\mathrm{X}-100$ in $1 \times \mathrm{PBS}$ for $1 \mathrm{~h}$. Sections were incubated in rabbit anti-tyrosine hydroxylase (TH) (1:1000; Calbiochem) and goat anti-AKAP150 (1:500; Santa Cruz Biotechnology) in carrier solution $(0.5 \%$ NHS in $0.1 \%$ Triton $\mathrm{X}-100$ in $1 \times \mathrm{PBS}$ ) overnight at room temperature. After rinsing in $1 \times$ PBS, sections were incubated for $2 \mathrm{~h}$ in Alexa Flour 488-labeled chicken anti-goat IgG and Alexa Flour 568-labeled donkey anti-rabbit IgG (both diluted 1:200). Finally, sections were rinsed in 1× PBS, dried, and coverslipped with Prolong mounting medium containing DAPI to permit visualization of nuclei. Background staining was assessed by omission of primary antibody in the immunolabeling procedure (negative control). VTA tissue sections of rats with previously established presence of TH/ AKAP150 immunoreactive neurons were processed as positive control tissue. Images were captured using a Carl Zeiss Pascal Confocal Inverted Microscope System with $100 \times / 1.4$ numerical aperture oil-immersion objective.

\section{Results}

Synaptic LFS with modest depolarization (a pairing LTD protocol) induced LTD of the $\mathrm{GABA}_{\mathrm{A}} \mathrm{R}$-mediated evoked IPSCs onto VTA DA neurons as we reported previously (Dacher and Nugent, 2011b). However, in response to the same pairing stimulation paradigm, GABAergic synapses onto VTA GABAergic neurons (lacking $I_{\mathrm{h}}$ current) did not exhibit the IPSC LTD GABA $_{\text {(Fig. } 1 a-}$ c), suggesting that $\mathrm{I}_{\mathrm{h}}{ }^{(-)}$neurons (presumably GABAergic neurons) differed from $\mathrm{I}_{\mathrm{h}}{ }^{(+)}$neurons because none of the former exhibited $\mathrm{LTD}_{\mathrm{GABA}}$. Because of the increasing recognition of heterogeneity among DA neurons in regard to their intrinsic electrophysiological properties, responses to external stimuli, and projection target (Ford et al., 2006; Margolis et al., 2006b; Lammel et al., 2008, 2011), in the present study, we consistently recorded from a region of the VTA (in the dorsal and caudal VTA) that is shown to contain mostly NAc-projecting DA neurons with $I_{\mathrm{h}}$ positivity (Margolis et al., 2006a,b). Therefore, the expression of $\mathrm{LTD}_{\mathrm{GABA}}$ might be one uniform physiological property of $I_{\mathrm{h}}$-expressing neurons in the caudal VTA and may be specific to NAc-projecting DA neurons.

\section{Postsynaptic depolarization or presynaptic stimulation is necessary but not sufficient to induce LTD $_{\mathrm{GABA}}$}

The LTD induction protocol is a pairing paradigm so it is unknown whether either low-frequency presynaptic stimulation or postsynaptic depolarization alone is sufficient to induce 


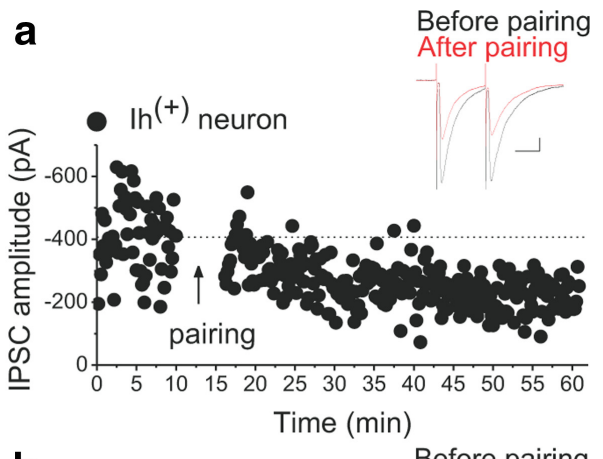

b $\quad \begin{aligned} & \text { Before pairing } \\ & \text { After pairing }\end{aligned}$

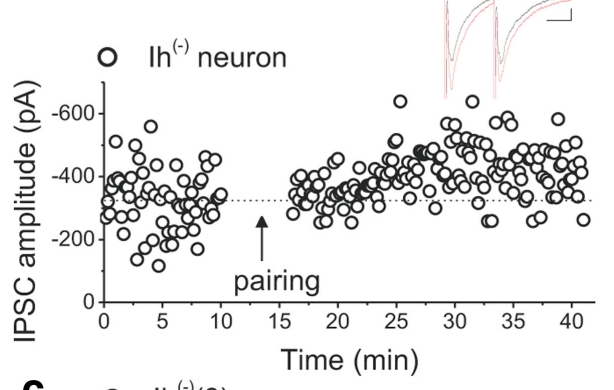

C $\bigcirc \mathrm{Ih}^{(-)}(8)$

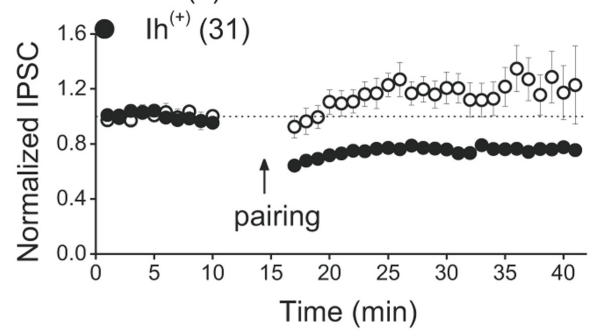

d

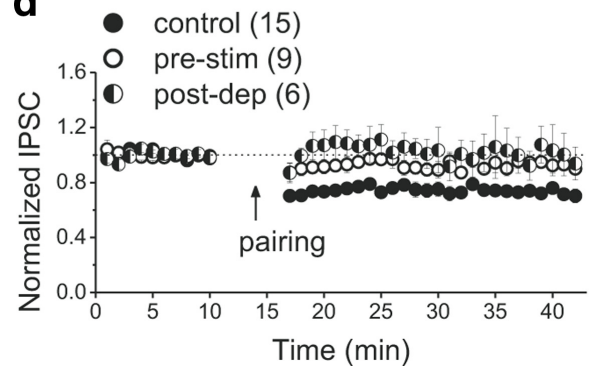

Figure 1. $\mathrm{LTD}_{\mathrm{GABA}}$ is selectively expressed in DA neurons. $\boldsymbol{a}, \boldsymbol{b}$, Single experiments showing induction of $\mathrm{LTD}_{G A B A}$ recorded in $I_{\mathrm{h}}{ }^{(+)}$(presumably DA) and $I_{\mathrm{h}}{ }^{(-)}$(presumably GABAergic) neurons, respectively $\left(l_{\mathrm{h}}{ }^{(+)}\right.$neurons, $75.9 \pm 1.2 \%$ of pre-pairing values, repeated-measures ANOVA, $F_{(3,85)}=$ $31.668, p<0.0001 ; /_{h}{ }^{(-)} /$GABAergic neurons, $122 \pm 5 \%$ of pre-pairing values, $F_{(3.6,14.5)}=3.132$, $p=0.051)$. At the arrow, LTD was induced using LFS while cells were depolarized at $-40 \mathrm{mV}$. In this and all figures, "pairing" represents the LTD induction protocol. Insets, Averaged IPSCs before (black) and $25 \mathrm{~min}$ after (red) pairing. In this and all figures, 10 consecutive traces from each condition were averaged for illustration as inset. Calibration: $50 \mathrm{pA}, 25 \mathrm{~ms}$. c, Average experiments from $I_{\mathrm{h}}{ }^{(+)}$(filled symbols) and $I_{\mathrm{h}}{ }^{(-)}$(open symbols) neurons. $I_{\mathrm{h}}{ }^{(+)}$but not $I_{\mathrm{h}}{ }^{(-)}$VTA neurons express LTD $_{\text {GABA }}$. All $I_{h}{ }^{(+)}$cells recorded as controls throughout the present work (except DMSO control cells) are included for the average from $I_{\mathrm{h}}{ }^{(+)}$neurons in this graph. $\boldsymbol{d}$, Average experiments illustrating the absence of $\mathrm{LTD}_{\mathrm{GABA}}$ in response to low-frequency presynaptic stimulation in which cells were voltage clamped at -70 to $-90 \mathrm{mV}$ while receiving LFS (pre-stim, open symbols) or postsynaptic depolarization in which cells were voltage clamped at $-40 \mathrm{mV}$ without receiving LFS (post-dep, half-filled symbols). Control experiments (filled symbols) were conducted in response to the LTD pairing protocol (cells were voltage clamped at $-40 \mathrm{mV}$ during the delivery of LFS) (control LTD, $74 \pm 3 \%$ of pre-pairing values, $F_{(4,48.37)}=18.055, p<0.0001$; pre-stim cells, $91 \pm 1 \%$ of pre-LFS values, $F_{(6,42)}=1.149$, $p=0.352$; post-dep cells, $102 \pm 7 \%$ of pre-depolarization values, $\left.F_{(2,6.15)}=0.501, p=0.633\right)$. Pairing of presynaptic stimulation and postsynaptic depolarization is necessary for successful induction of $\mathrm{LTD}_{\mathrm{GABA}}$. Values shown throughout figure are the mean $\pm \mathrm{SEM}$.
$\mathrm{LTD}_{\mathrm{GABA}}$. To test these individual components of the pairing protocol, we first attempted to induce $\mathrm{LTD}_{\mathrm{GABA}}$ while cells were voltage clamped at -70 to $-95 \mathrm{mV}$ during the induction protocol to minimize postsynaptic depolarization. Under these conditions, low-frequency presynaptic stimulation failed to induce $\mathrm{LTD}_{\mathrm{GABA}}$, suggesting that at least some voltage-dependent processes may be critical for the induction of $\operatorname{LTD}_{\mathrm{GABA}}$ (Fig. $1 d$, pre-stim experiments). Given that L-type voltage-gated $\mathrm{Ca}^{2+}$ channels (VGCCs) can provide the postsynaptic $\mathrm{Ca}^{2+}$ entry necessary for synaptic plasticity (Morishita and Sastry, 1996; Kreitzer and Malenka, 2005; Adermark and Lovinger, 2007) and the fact that $\mathrm{LTD}_{\mathrm{GABA}}$ is NMDA receptor (NMDAR)-independent, we tested whether L-type VGCCs were activated by postsynaptic depolarization during the induction protocol to trigger $\mathrm{LTD}_{\mathrm{GABA}}$. We attempted to induce $\mathrm{LTD}_{\mathrm{GABA}}$ in the presence of the L-type VGCC blocker nifedipine $(50 \mu \mathrm{M})$. Nifedipine did not block LTD $_{\text {GABA }}$ (control LTD, $70 \pm 0.8 \%$ of pre-pairing values, $F_{(10.3,41.2)}=7.721, p<0.0001, n=6$; nifedipine cells, $69 \pm 1 \%$ of pre-pairing values, $\left.F_{(3,9.03)}=4.989, p=0.026, n=4\right)$, suggesting that postsynaptic depolarization engages voltage-dependent signaling molecules other than NMDAR or L-type VGCCs to facilitate LTD induction. Interestingly, postsynaptic depolarization per se was also unable to induce plasticity when the cells were voltage clamped at $-40 \mathrm{mV}$ for $6 \mathrm{~min}$ without receiving lowfrequency presynaptic stimulation (Fig. $1 d$, post-dep experiments). Altogether, our data suggest that the pairing of presynaptic and postsynaptic events is critical for the successful induction of $\mathrm{LTD}_{\mathrm{GABA}}$. Given that electrical stimulation during LTD induction protocol is not specific to GABAergic terminals, it could also trigger somatodendritic release of DA and other neurotransmitters that may contribute to LTD.

\section{Disruption of postsynaptic G-protein signaling blocks LTD $_{\text {GABA }}$}

LTD $_{\text {GABA }}$ appears to be expressed postsynaptically (through a reduction in the number or conductance of postsynaptic $\mathrm{GABA}_{\mathrm{A}} \mathrm{Rs}$ ), because we showed previously that the PPR and coefficient of variation, the two main indicators of presynaptic plasticity, were unaffected after LTD induction (Dacher and Nugent, 2011b). Additionally, we found that, in contrast to the presynaptic cocaine-induced inhibitory LTD (I-LTD) in the VTA (Pan et al., 2008a), cannabinoid $\mathrm{CB}_{1}$ receptors are not required for induction of $\mathrm{LTD}_{\mathrm{GABA}}$, indicating that these two forms of I-LTD in the VTA are triggered by distinct mechanisms. However, both I-LTD and LTD $_{\mathrm{GABA}}$ require activation of $\mathrm{D}_{2}$ Rs, although it was proposed that the $\mathrm{D}_{2}$ Rs involved in I-LTD are located presynaptically on GABAergic terminals (Pan et al., 2008b; Dacher and Nugent, 2011b). To provide additional evidence for the postsynaptic nature of $\mathrm{LTD}_{\mathrm{GABA}}$ and the involvement of postsynaptic $\mathrm{D}_{2} \mathrm{Rs}$ in $\mathrm{LTD}_{\mathrm{GABA}}$, we blocked the activation of G-proteincoupled receptors (GPCRs) in the postsynaptic cell by including guanosine $5^{\prime}-O-(\beta$-thiodiphosphate (GDP $\beta S, 200 \mu \mathrm{M})$ in the recording pipette. Intra-pipette GDP $\beta$ S completely blocked $\mathrm{LTD}_{\mathrm{GABA}}$, confirming that $\mathrm{LTD}_{\mathrm{GABA}}$ is postsynaptic and its induction is dependent on activation of postsynaptic GPCRs, such as $\mathrm{D}_{2}$ autoreceptors (Fig. $2 a$ ). GPCRs coupling through $\mathrm{G}_{\mathrm{i}} / \mathrm{G}_{\mathrm{o}}$ - or $\mathrm{G}_{\mathrm{q} / 11}$-proteins, such as $\mathrm{GABA}_{\mathrm{B}} \mathrm{R}$ and group I metabotropic glutamate receptors (mGluRs), respectively, are also located postsynaptically on VTA DA neurons (Johnson and North, 1992; Cameron and Williams, 1994; Fiorillo and Williams, 1998) and are shown to play an important role in the induction of LTD (Bellone and Lüscher, 2005; Kamikubo et al., 2007; Lüscher and Huber, 2010; Tadavarty et al., 2011). Therefore, we further 

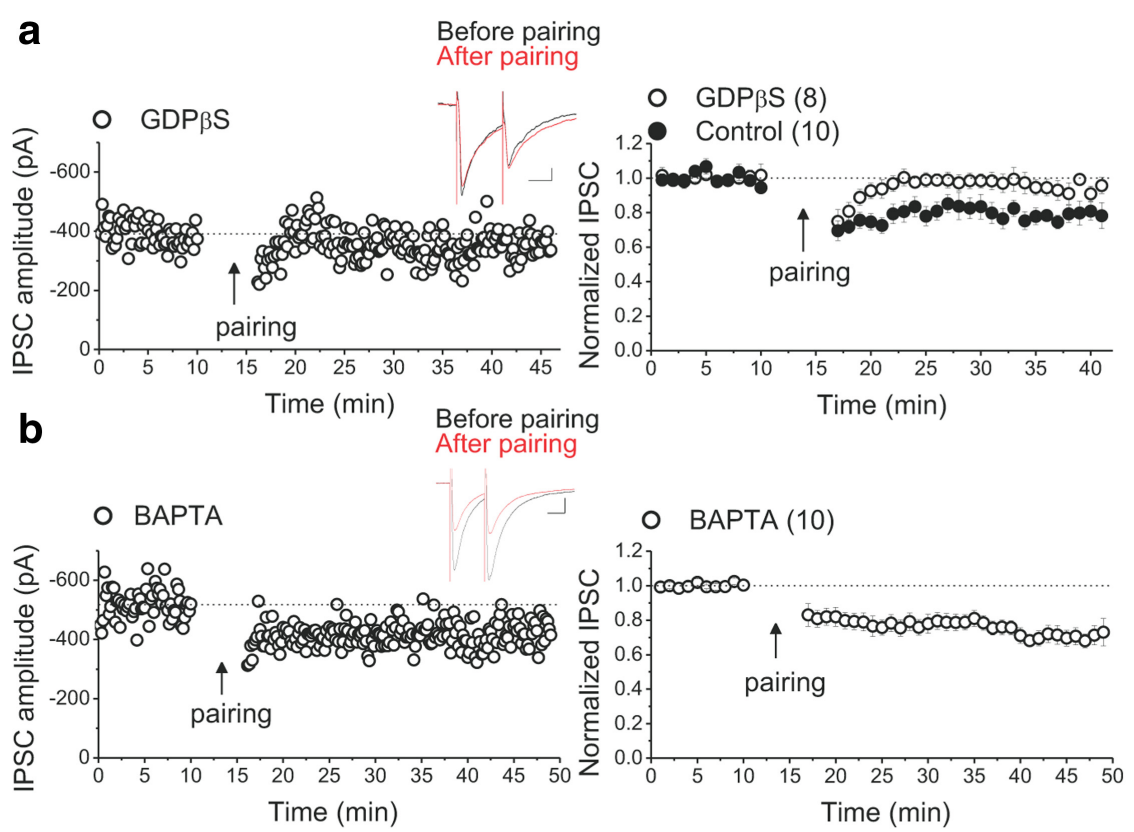

C
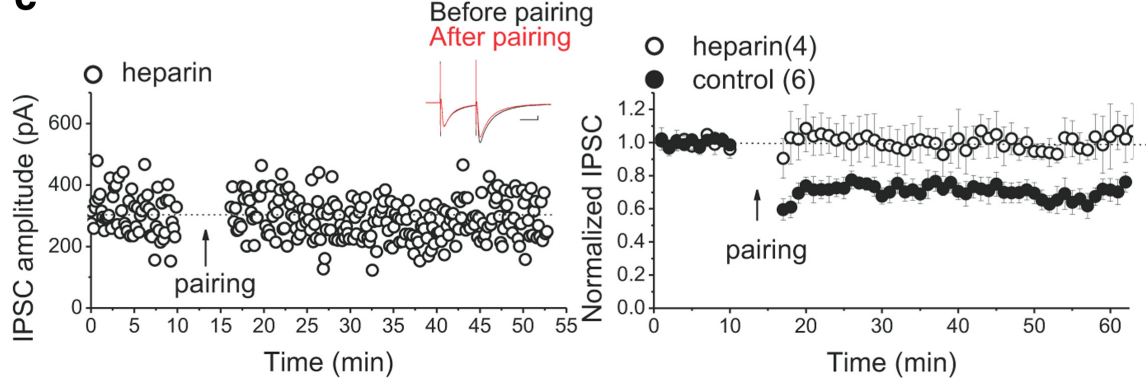

Figure 2. The induction of $\mathrm{LTD}_{\mathrm{GABA}}$ requires postsynaptic $\mathrm{G}$-protein signaling and $\mathrm{IP}_{3} \mathrm{R}$-mediated $\mathrm{Ca}^{2+}$ release, but chelating postsynaptic $\mathrm{Ca}^{2+}$ does not block $\mathrm{LTD}_{G A B A} \cdot \boldsymbol{a}$, Single experiment illustrating the block of $\mathrm{LTD}_{\mathrm{GABA}}$ by intra-pipette GDP $\beta$ S and averaged experiments with (open symbols) and without (filled symbols) $200 \mu \mathrm{m} \mathrm{GDP} \beta S$ in the pipette solution (control LTD, 78 土 $1 \%$ of pre-pairing values, $F_{(2.28 .20 .55)}=8.635, p=0.0014 ; G D P \beta S$ cells, $94 \pm 2 \%$ of pre-pairing values, $F_{(22.11 .2)}=0.198, p=$ 0.846). Inset, Averaged IPSCs before (black) or $25 \mathrm{~min}$ after (red) pairing. Calibration: 50 pA, 25 ms. Disruption of postsynaptic $G$-protein signaling prevents $L_{T D}{ }_{G A B A} \cdot \boldsymbol{b}$, Single experiment illustrating the induction of $L_{T D_{G A B A}}$ with intra-pipette BAPTA and averaged experiment with $20-30 \mathrm{~mm}$ BAPTA in the pipette solution (open symbols, BAPTA cells, $73 \pm 2 \%$ of pre-pairing values, $\left.F_{(3,18.39)}=18.37, p<0.0001\right)$. Inset, Averaged IPSCs before (black) or $25 \mathrm{~min}$ after (red) pairing. Calibration: 50 pA, 25 ms. Intra-pipette BAPTA does not block $\operatorname{LTD}_{G A B A} \cdot c$, Single experiment illustrating the block of $\operatorname{LTD}_{G A B A}$ by intrapipette heparin and averaged experiments with (open symbols) and without (filled symbols) $2 \mathrm{mg} / \mathrm{ml}$ heparin in the pipette solution (control LTD, $70 \pm 0.8 \%$ of pre-pairing values, $F_{(10.3 .41 .2)}=7.721, p<0.0001$; heparin cells, $1.002 \pm$ $3.5 \%$ of pre-pairing values, $\left.F_{(6.17,12.35)}=0.634, p=0.705\right)$. Inset, Averaged IPSCs before (black) or $25 \mathrm{~min}$ after (red) pairing. Calibration: $50 \mathrm{pA}, 25 \mathrm{~ms}$. IP ${ }_{3} \mathrm{R}$ blockade abolishes $\mathrm{LTD}_{\mathrm{GABA}}$.

investigated the possible contribution of $\mathrm{GABA}_{\mathrm{B}} \mathrm{Rs}$ and group I mGluRs in the induction of $\mathrm{LTD}_{\mathrm{GABA}}$. We attempted to induce LTD $_{\mathrm{GABA}}$ in the presence of a potent $\mathrm{GABA}_{\mathrm{B}} \mathrm{R}$ antagonist CGP $54626\left(\left[S-\left(R^{\star}, R^{\star}\right)\right]\right.$-[3-[[1-(3,4-dichlorophenyl)ethyl] amino]-2hydroxypropyl] (cyclohexylmethyl)phosphinicacid) (500 nM to 1 $\mu \mathrm{M})$. CGP 54626 did not block LTD, suggesting that $\mathrm{GABA}_{\mathrm{B}} \mathrm{Rs}$ are not critical for the induction of $\mathrm{LTD}_{\mathrm{GABA}}$ (control LTD, $70 \pm$ $0.8 \%$ of pre-pairing values, $F_{(0.3,41.2)}=7.721, p<0.0001, n=6$; CGP54626 cells, $73.5 \pm 2 \%$ of pre-pairing values, $F_{(6.2,18.8)}=$ 3.951, $p=0.009, n=5)$. Using two different group I mGluR blockers, $500 \mathrm{~mm}(S)$-MCPG [( \pm )-amino-4-carboxy-methylphenylacetic acid] and $10 \mu \mathrm{M}$ A841720 [(4-bromo-3-fluorophenyl)hydrazine hydrochloride], we also tested whether group I mGluR activation is necessary for the induction of LTD $_{\mathrm{GABA}}$. LTD $_{\text {GABA }}$ was successfully induced in response to pairing protocol in the presence of either (S)-MCPG or A841720, suggesting that activation of group I mGluRs is also not required for the induction of $\mathrm{LTD}_{\mathrm{GABA}}$ (control LTD, $70 \pm 0.8 \%$ of pre-pairing values, $F_{(10.3,41.2)}=7.721, p<0.0001, n=6$; group I mGluR antagonist cells, $74 \pm 2 \%$ of pre-pairing values, $F_{(4.7,23.54)}=2.829$, $p=0.04, n=6$ ).

\section{$\mathrm{IP}_{3} \mathrm{R}$ blockade abolishes $\mathrm{LTD}_{\mathrm{GABA}}$, whereas chelation of intracellular calcium does not block LTD $_{\mathrm{GABA}}$} Similar to the majority of synaptic plasticity at excitatory synapses, most LTP/LTD of GABAergic synapses is dependent on a rise in postsynaptic $\mathrm{Ca}^{2+}$ and NMDAR activation (Castillo et al., 2011). To test whether postsynaptic $\mathrm{Ca}^{2+}$ signaling is also necessary for $\mathrm{LTD}_{\mathrm{GABA}}$, we performed experiments using $20-30 \mathrm{~mm}$ BAPTA in the recording pipette to buffer the fast rises in intracellular $\mathrm{Ca}^{2+}$ during LTD induction. We tested LTD at both glutamatergic and GABAergic synapses onto DA neurons using the LTD pairing paradigm. As shown previously (Jones et al., 2000), we confirmed that glutamatergic LTD in VTA DA neurons is calcium dependent and blocked by $30 \mathrm{~mm}$ BAPTA (data not shown; control LTD, $78 \pm 0.3 \%$ of pre-pairing values, $F_{(2.85,11.39)}=3.587$, $p<0.05, n=5$; BAPTA cells, $97 \pm 2 \%$ of pre-pairing values, $F_{(39.66,79.33)}=0.618$, $p=0.912, n=3)$. Surprisingly, we found that intra-pipette BAPTA was unable to block $\operatorname{LTD}_{\mathrm{GABA}}$ (Fig. 2b). Consistent with this result, the blockade of VGCCs with nifedipine did not affect $\mathrm{LTD}_{\mathrm{GABA}}$, raising the possibility that $\operatorname{LTD}_{\mathrm{GABA}}$ might be $\mathrm{Ca}^{2+}$ independent. However, it was also possible that a discrete local rise in intracellular $\mathrm{Ca}^{2+}$ as a result of $\mathrm{D}_{2} \mathrm{R}$-mediated mobilization of intracellular $\mathrm{Ca}^{2+}$ stores could trigger LTD. In fact, compelling evidence suggests that $\mathrm{D}_{2} \mathrm{Rs}$ can facilitate $\mathrm{Ca}^{2+}$ signaling through an $\mathrm{IP}_{3} \mathrm{R}$-mediated signaling pathway in the striatum and NAc (Hernandez-Lopez et al., 2000; Hu et al., 2005), which could underlie $\mathrm{LTD}_{\mathrm{GABA}}$ in the VTA. To test this possibility, we attempted to induce $\mathrm{LTD}_{\mathrm{GABA}}$ in response to the pairing protocol in the presence of the $\mathrm{IP}_{3} \mathrm{R}$ antagonist heparin (intrapipette heparin, $2 \mathrm{mg} / \mathrm{ml}$ ) (Komatsu, 1996). Postsynaptic intrapipette application of heparin completely blocked $\mathrm{LTD}_{\mathrm{GABA}}$, suggesting that a postsynaptic $\mathrm{IP}_{3} \mathrm{R}$-induced $\mathrm{Ca}^{2+}$ release occurs during the induction of $\mathrm{LTD}_{\mathrm{GABA}}$ (Fig. 2c).

\section{Inhibition of CaN activity blocks LTD $_{\mathrm{GABA}}$}

Expression of a postsynaptic LTD of GABAergic synapses could be achieved through activation of protein phosphatase (PPs), which dephosphorylate $\mathrm{GABA}_{\mathrm{A}} \mathrm{Rs}$ or their associated regulatory subunit (Morishita and Sastry, 1996). Several PPs, including PPI, PP2A, and $\mathrm{Ca}^{2+} /$ calmodulin-dependent PP (PP2B/also known as $\mathrm{CaN}$ ), have been shown to participate in postsynaptic as well as presynaptic expression of LTD of excitatory and inhibitory synapses (Collingridge et al., 2010; Castillo et al., 2011). Among 
them, $\mathrm{CaN}$ is of particular interest because it has been shown that stimulation of striatal $\mathrm{D}_{2}$ Rs can modulate the striatal excitability through an $\mathrm{IP}_{3} \mathrm{R}-\mathrm{CaN}$ signaling cascade (Hernandez-Lopez et al., 2000; $\mathrm{Hu}$ et al., 2005), and $\mathrm{D}_{2} \mathrm{R}$ activation can cause dephosphorylation of intracellular signaling molecules in a CaN-dependent manner (Nishi et al., 1997; Greengard, 2001). Furthermore, in the context of addiction, the reinforcing effects of chronic amphetamine or morphine are impaired in a mouse strain overexpressing $\mathrm{CaN}$, suggesting a critical role for $\mathrm{CaN}$ in the learning mechanisms involved in drug addiction (Biala et al., 2005). Given that LT$\mathrm{D}_{\mathrm{GABA}}$ is also $\mathrm{IP}_{3} \mathrm{R}$ and $\mathrm{D}_{2} \mathrm{R}$ dependent, we next asked whether $\mathrm{CaN}$ is an absolute requisite for expression of $\mathrm{LTD}_{\mathrm{GABA}}$. LTD induction was attempted in midbrain slices in the presence of two different $\mathrm{CaN}$ inhibitors: intra-pipette FK506 (0.6-1 $\mu \mathrm{M})$ or bath application of cyclosporin A $(1 \mu \mathrm{M})$ with a previous $2 \mathrm{~h}$ incubation of slices in the drug. We found that both $\mathrm{CaN}$ inhibitors blocked $\mathrm{LTD}_{\mathrm{GABA}}$ (Fig. $3 a, b)$. Our data suggest that $\mathrm{D}_{2} \mathrm{R}$ activation triggers $\mathrm{LTD}_{\mathrm{GABA}}$ through an $\mathrm{IP}_{3}-$ CaN-dependent signaling mechanism.

\section{$\mathrm{D}_{2} \mathrm{R}$ stimulation mimics and occludes LTD $_{\text {GABA }}$ through postsynaptic PKA inhibition with a CaN-dependent mechanism}

Inhibition of $\mathrm{LTD}_{\mathrm{GABA}}$ with CaN blockers suggest that dephosphorylation of $\mathrm{GABA}_{\mathrm{A}}$ Rs by $\mathrm{CaN}$ could be a mechanism for expression of $\mathrm{LTD}_{\mathrm{GABA}} \cdot \mathrm{D}_{2} \mathrm{R}$ activation is also a part of signaling pathway that triggers $\mathrm{LTD}_{\mathrm{GABA}}$ (Dacher and Nugent, 2011b), and activation of CaN downstream to $D_{2} R$ has been shown to be $\mathrm{IP}_{3} \mathrm{R}-\mathrm{Ca}^{2+}$ dependent (Hernandez-Lopez et al., 2000; Hu et al., 2005) and facilitated via a $G_{i}-G_{o}-$ adenylyl cyclase-cAMP-PKA pathway (Hu et al., 2005). Thus, we next examined whether $\mathrm{D}_{2} \mathrm{R}$ stimulation through its inhibitory effects on postsynaptic PKA is enough to depress GABAergic transmission in a CaN-dependent manner. A continuous or a brief $10 \mathrm{~min}$ bath application of $20 \mu \mathrm{M}$ quinpirole (the $\mathrm{D}_{2} \mathrm{R}$ agonist) reliably reduced the amplitude of $\mathrm{GABA}_{\mathrm{A}}$ IPSCs (Fig. $4 a, b$ ), without affecting the PPR (IPSC2/IPSC1; PPR before quinpirole, $0.99 \pm$ 0.034; PPR of the peak response to quinpirole, $0.89 \pm 0.19 ; n=$ $\left.11 ; F_{(2.42,16.45)}=1.445, p=0.265\right)$, and this quinpirole-induced depression was $\mathrm{CaN}$ dependent because postsynaptic infusion of cyclosporine A $(1 \mu \mathrm{M})$ significantly prevented this chemical depression (Fig. 4b). Moreover, once the depression with quinpirole reached a stable baseline, the LTD induction protocol using the pairing paradigm ( $1 \mathrm{~Hz}$ LFS at $-40 \mathrm{mV}$ ) did not induce additional $\mathrm{LTD}_{\mathrm{GABA}}$ (occlusion) (Fig. $4 a, c$ ). Altogether, the present results confirm our previous finding (Dacher and Nugent, $2011 \mathrm{~b}$ ) that transient activation of postsynaptic $\mathrm{D}_{2} \mathrm{R}$ is sufficient to induce $\mathrm{LTD}_{\mathrm{GABA}}$.

To further demonstrate that quinpirole acts via postsynaptic $\mathrm{D}_{2}$ Rs to inhibit the PKA pathway and induce $\mathrm{LTD}_{\mathrm{GABA}}$, a membrane-impermeant PKA inhibitor, $\mathrm{PKI}_{(6-22)}$, was used in the intracellular pipette. Similar to excitatory synapses in the CA1
Before pairing

After pairing
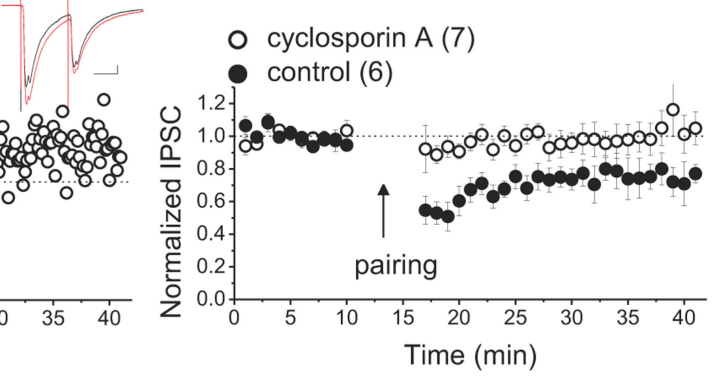

Before pairing

After pairing
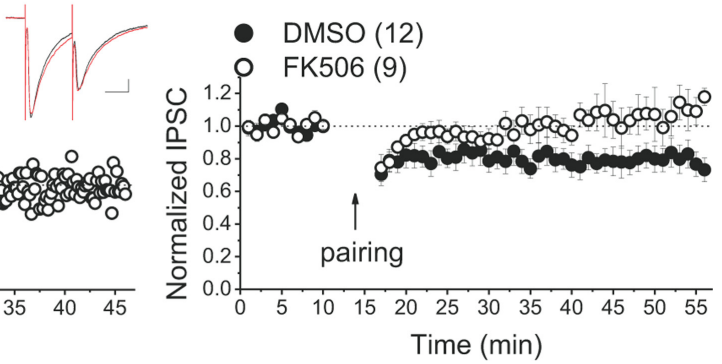

Time (min)

$\begin{array}{ccc}20 & 25 & 30 \\ \text { Time } & (\min )\end{array}$

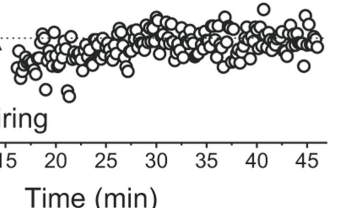

Figure 3. $\mathrm{LTD}_{\mathrm{GABA}}$ requires the activity of postsynaptic $\mathrm{CaN}$. $\boldsymbol{a}$, Single experiment illustrating the block of $\mathrm{LTD}_{\mathrm{GABA}}$ by preincu-

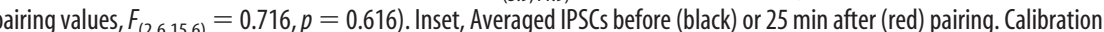
.

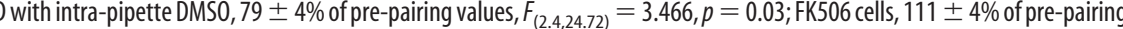
values, $F_{(1.7,6.9)}=0.477, p=0.614$ ). Inset, Averaged IPSCs before (black) or $25 \mathrm{~min}$ after (red) pairing. Calibration: $50 \mathrm{pA}, 25 \mathrm{~ms}$. Intra-pipette FK506 prevents $\mathrm{LTD}_{\mathrm{GABA}}$.

region of hippocampus (Kameyama et al., 1998), intracellular inclusion of $\mathrm{PKI}_{(6-22)}$ induced a significant reduction in IPSC amplitude within $12 \pm 1.2 \mathrm{~min}$ after initiation of the wholecell recording with $\mathrm{PKI}_{(6-22)}$-filled pipettes (Fig. $4 d, e$ ), and this $\mathrm{PKI}_{(6-22)}$-induced depression of IPSCs occluded pairinginduced $\mathrm{LTD}_{\mathrm{GABA}}$ (Fig. $4 d-f$ ). Remarkably intra-pipette $\mathrm{PKI}_{(6-22)}$-induced rundown of GABAergic transmission was postsynaptic (PPR values did not change after $\mathrm{PKI}_{(6-22)}$ treatment; baseline PPR, $1.02 \pm 0.015$; PPR of the peak response to $\left.\mathrm{PKI}_{(6-22)}, 1.027 \pm 0.3 ; n=21 ; F_{(1.9,28.69)}=1.448, p=0.251\right)$ and was also prevented by preincubation and bath application of cyclosporine A ( $1 \mu \mathrm{M})$, suggesting that, similar to quinpirole-induced depression and pairing-induced $\mathrm{LTD}_{\mathrm{GABA}}$, LTD of PKI $\mathrm{PT}_{(6-22)}{ }^{-}$ loaded neurons is also CaN dependent (Fig. 4e). Moreover, once PKI-induced depression plateaued, we bath applied quinpirole. The PKI-induced depression occluded additional quinpirole-induced synaptic depression, suggesting that $\mathrm{D}_{2} \mathrm{R}$ activation acts via PKA inhibition to induce $\mathrm{LTD}_{\mathrm{GABA}}$ (Fig. $4 g$ ). It should be noted that, in all experiments performed with quinpirole, $\mathrm{CsCl}$ internal solution was used in the intracellular pipette instead of $\mathrm{KCl}$ to exclude the possibility that the observed effects of quinpirole were attributable to $\mathrm{D}_{2} \mathrm{R}$ activation of the G-protein-coupled inwardly-rectifying potassium channels and not through inhibition of PKA. Collectively, these experiments indicate that $\mathrm{D}_{2} \mathrm{R}$ stimulation through postsynaptic PKA inhibition induces the CaN-dependent LT$\mathrm{D}_{\mathrm{GABA}}$. 


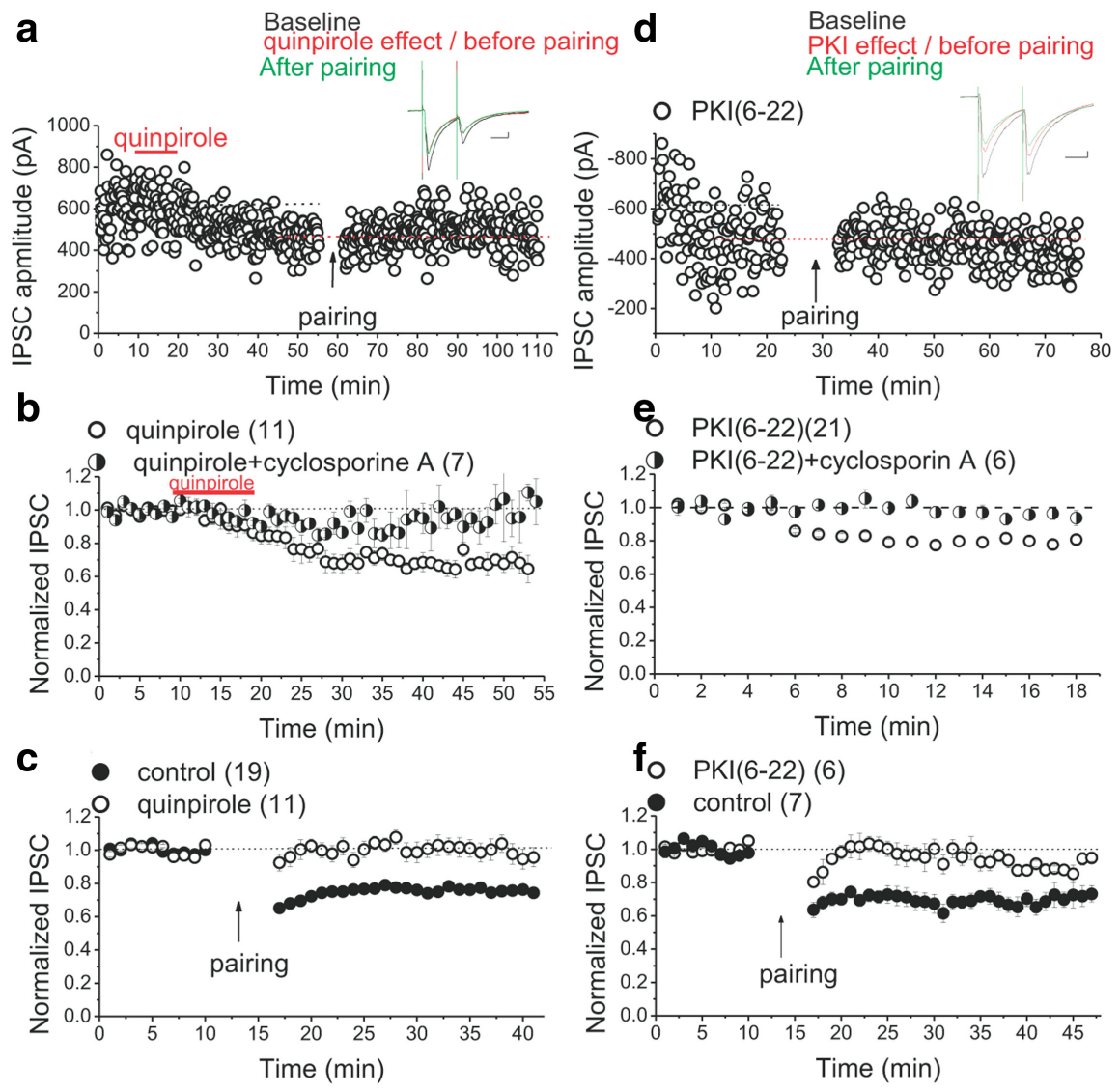

g $\bigcirc \mathrm{PKI}(6-22)+$ quinpirole $(5)$

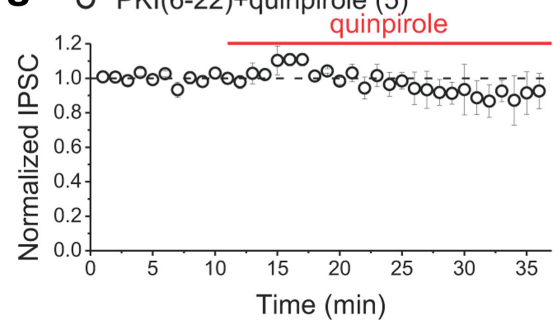

Figure 4. Postsynaptic $D_{2} R$ stimulation and inhibition of PKA mimic and occlude $L_{T D} D_{G A B A}$ in a $C a N$-dependent manner. $\boldsymbol{a}$ Single experiment illustrating the effect of a $10 \mathrm{~min}$ (see bar) bath application of $20 \mu \mathrm{m}$ quinpirole on basal synaptic transmission and the induction of pairing-induced $\mathrm{LTD}_{\mathrm{GABA}}$ (only $5 \mathrm{~min}$ of the baseline before the emergence of the quinpirole-induced depression is shown in this sample experiment). Inset, Averaged IPSCs before (black) or the peak response of quinpirole (red) or $25 \mathrm{~min}$ after pairing (green). Calibration: 50 pA, $25 \mathrm{~ms}$. $\boldsymbol{b}$, Averaged experiments with bath application of $20 \mu \mathrm{m}$ quinpirole (open symbols) or $20 \mu \mathrm{m}$ quinpirole plus intra-pipette cyclosporin A (1 $\mu \mathrm{m}$, half-filled symbols). A continuous or a brief 10 min exposure of midbrain slices to quinpirole induces a rapid rundown of IPSCs that is blocked by cyclosporin A treatment (quinpirole cells, $67 \pm 1.6 \%$ of the first 5 min baseline values, $F_{(9.6,74.9)}=9.707, p<$ 0.0001 ; quinpirole plus cyclosporine $A, 95 \pm 4 \%$ of the pre-quinpirole values, $\left.F_{(2.85 .64)}=1.106, p=0.417\right)$. $c$, Averaged LTD induction experiments with (open symbols) or without (filled symbols) quinpirole . Quinpirole-induced depression occludes pairing-induced $\mathrm{LTD}_{\mathrm{GABA}}$ (control LTD, $75 \pm 0.8 \%$ of pre-pairing values, $F_{(11,177.36)}=19.121, p<0.0001$; quinpirole, $98 \pm 3.7 \%$ of pre-pairing values, $\left.F_{(9.4,84.7)}=0.973, p=0.470\right)$. $\boldsymbol{d}$, Single experiment illustrating the effect of intra-pipette $\mathrm{PKI}_{(6-22)}$ on basal synaptic transmission and the induction of pairing-induced $\mathrm{LTD}_{\mathrm{GABA}}$ in the $\mathrm{PKI}_{(6-22)}$-loaded cell (only 5 min of the baseline before the emergence of the $\mathrm{PKI}_{(6-22)}$-induced depression is shown in this sample experiment). Inset, Averaged IPSCs before (black) or the peak response of $\mathrm{PKI}_{(6-22)}$ (red) or $25 \mathrm{~min}$ after pairing (green). Calibration: $50 \mathrm{pA}, 25 \mathrm{~ms}$. $\boldsymbol{e}$, Averaged experiments with intra-pipette $10 \mu \mathrm{m} \mathrm{PKI}{ }_{(6-22)}$ (open symbols) or intra-pipette 10 $\mu \mathrm{M} \mathrm{PKI}_{(6-22)}$ plus $1 \mu \mathrm{m}$ cyclosporin A (half-filled symbols). PKI ${ }_{(6-22)}$ induces a rapid rundown of IPSCs that is blocked by cyclosporin A treatment (PKI cells, $75 \pm 3 \%$ of the first 5 min baseline values, $F_{(2.03,25.5)}=70.525, p<0.0001 ; \mathrm{PKI}_{(6-22)}$ plus cyclosporine $A, 95 \pm 4 \%$ of the first 5 min baseline values, $\left.F_{(3,15)}=1.634, p=0.224\right)$. $\boldsymbol{f}$, Averaged LTD induction experiments with (open symbols) or without (filled symbols) intra-pipette PKI ${ }_{(6-22)}$. LTD induction was attempted at 30 min or later after the initiation of the whole cell recording with intra-pipette PKI. PKI ${ }_{(6-22)}$-induced depression occludes pairing-induced $\mathrm{LTD}_{\mathrm{GABA}}$ (control LTD, $71 \pm 1 \%$ of pre-pairing values, $F_{(5.27,25.35)}=7.167, p<0.0001 ; \mathrm{PKI}_{(6-22)}$ cells, $90 \pm 4.2 \%$ of pre-pairing values, $\left.F_{(1.85,7.4)}=1.899, p=0.216\right)$. $g$, Averaged experiments with intra-pipette $10 \mu \mathrm{M}$ $\mathrm{PKI}_{(6-22)}$ plus quipirole (open symbols). Intra-pipette $\mathrm{PKI}_{(6-22)}$ occludes quinpirole-induced depression of IPSCs (quinpirole plus PKI cells, $90 \pm 3 \%$ of the pre-quinpirole values, $F_{(3.7,7.434)}=1.127, p=0.409$ ).
Disruption of PKA-AKAP150 association at GABAergic but not glutamatergic synapses induces a CaN-dependent LTD

Phosphorylation of $\mathrm{GABA}_{\mathrm{A}} \mathrm{Rs}$ by PKA seems to mostly stabilize $\mathrm{GABA}_{A}$ Rs in the synapse. Conversely, dephosphorylation of kinase substrates by phosphatases may initiate endocytosis of $\mathrm{GABA}_{\mathrm{A}} \mathrm{Rs}$ (Luscher et al., 2011; Vithlani et al., 2011). AKAP150 specifically is an attractive candidate as mediator of this phosphorylation-dephosphorylation balance between PKA and CaN for LTD because it is well situated in the synapse to mediate both the effects of PKA and CaN on the regulation of the strength of glutamatergic and GABAergic synapses (Brandon et al., 2003; Snyder et al., 2005; Horne and Dell'Acqua, 2007; Bhattacharyya et al., 2009; Jurado et al., 2010). AKAP150 immunoreactivity has been observed in the midbrain (Glantz et al., 1992); however, the localization of AKAP150 in VTA DA neurons has not been reported previously. Therefore, we first used a double-immunofluorescence staining technique using antibodies against TH (marker for DA neurons) and AKAP150 to visualize DA neurons expressing AKAP150. Colabeled neurons expressing both AKAP150 and TH in the VTA of four rats at two AP levels within the VTA $[-4.9$ and $-5.1 \mathrm{~mm}$ caudal to bregma (Paxinos and Watson, 2007)] were scanned and quantified (the total number of cells counted was 447). All THpositive cells in the studied area of the VTA also expressed AKAP-150 immunoreactivity, whereas AKAP 150-positive cells that did not express TH immunoreactivity were also present (Fig. $5 a-c$ ). In the TH-positive cells, the AKAP150-immunoreactivity appeared as granular inclusions throughout the cytoplasm. Our experiments demonstrated for the first time that essentially all dopaminergic neurons in the VTA indeed express AKAP150, although a number of non-DA cells are also AKAP positive (Fig. $5 a-c$ ).

Next we tested whether disruption of PKA anchoring to AKAP150 would mimic LTD $_{\mathrm{GABA}}$. We used the anchoring inhibitor peptide $\mathrm{Ht} 31$, which binds to the PKA-binding site of a human thyroid AKAP and acts as a competitive antagonist of PKA anchoring to AKAPs but has no effect on PKA activity. In interleaved control experiments, we used Ht31p, the control peptide, as the negative control peptide (Snyder et al., 2005). Intra-pipette $\mathrm{Ht} 31(1 \mu \mathrm{M})$ caused a remarkable rapid rundown of synaptic transmission within $8.45 \pm 0.53 \mathrm{~min}$ after initiation of the 
whole-cell recording with $\mathrm{Ht} 31$-filled electrodes, whereas intra-pipette Ht31p control peptide $(1 \mu \mathrm{M})$ did not (Fig. $5 d, e)$. Similar to quinpirole- and $\mathrm{PKI}_{(6-22)^{-}}$ induced LTD, intra-pipette Ht31-induced rundown was postsynaptic (PPR values did not change after $\mathrm{Ht} 31$ treatment; baseline PPR, $1.056 \pm 0.02$; PPR of the peak response to Ht31, $1.019 \pm 0.2 ; n=$ $\left.19 ; F_{(1.47,26.54)}=1.334, p=0.275\right)$ and CaN dependent because this rundown was also prevented by preincubation and bath application of $1 \mu \mathrm{M}$ cyclosporine A (Fig. 5e). To further confirm that Ht31induced depression of IPSCs and LTD $_{\mathrm{GABA}}$ share a similar expression mechanism, we attempted to induce LTD using the LTD induction protocol in $\mathrm{Ht} 31$ - and $\mathrm{Ht} 31 \mathrm{p}-$ loaded cells. Once the depression by $\mathrm{Ht} 31$ had plateaued, LFS paired with depolarization failed to induce additional LTD in Ht31-filled neurons, whereas Ht31p-filled neurons still expressed LTD $_{\mathrm{GABA}}$ (Fig. $5 d, f$ ). The occlusion of LTD $_{\text {GABA }}$ with Ht31 further demonstrated that the displacement of PKA from AKAP150 is sufficient to allow for basal CaN activity. Given the established role of AKAP150 in glutamatergic transmission and plasticity, we next examined whether the PKA-AKAP150 association was necessary for AMPAR-mediated synaptic transmission in VTA DA neurons (only $I_{\mathrm{h}}{ }^{(+)}$neurons were recorded in these experiments). Remarkably, EPSCs were unaffected in $I_{\mathrm{h}}{ }^{(+)}$cells loaded with Ht31 or Ht31p, suggesting that the PKA-AKAP$\mathrm{CaN}$ complex may be uniquely situated at $\mathrm{GABA}_{\mathrm{A}} \mathrm{R}$ synapses to regulate the trafficking and plasticity associated with $\mathrm{GABA}_{\mathrm{A}} \mathrm{Rs}$ in VTA DA neurons (Fig. $5 g$ ).

\section{Clathrin-mediated endocytosis of $\mathrm{GABA}_{\mathrm{A}}$ Rs underlies the AKAP-CaN- dependent LTD $_{\mathrm{GABA}}$}

The common mechanism underlying the expression of many forms of postsynaptic glutamatergic LTD seems to involve a clathrin-mediated AMPAR endocytosis (Collingridge et al., 2010). Endocytosis of $\mathrm{GABA}_{\mathrm{A}} \mathrm{Rs}$ is also regulated through clathrin- and dynamin-dependent mechanisms involving scaffolding proteinmediated interaction of kinases and phosphatases with the $\mathrm{GABA}_{\mathrm{A}} \mathrm{R}$ subunits (Luscher et al., 2011). To test whether clathrin-mediated internalization of $\mathrm{GABA}_{\mathrm{A}}$ Rs underlie the expression of LT$\mathrm{D}_{\mathrm{GABA}}$ in VTA DA neurons, we postsynaptically applied a recently synthesized compound called Pitstop2 that selectively interferes with clathrin-mediated endocytosis of receptors by targeting the terminal domain of clathrin (von Kleist et al., 2011).
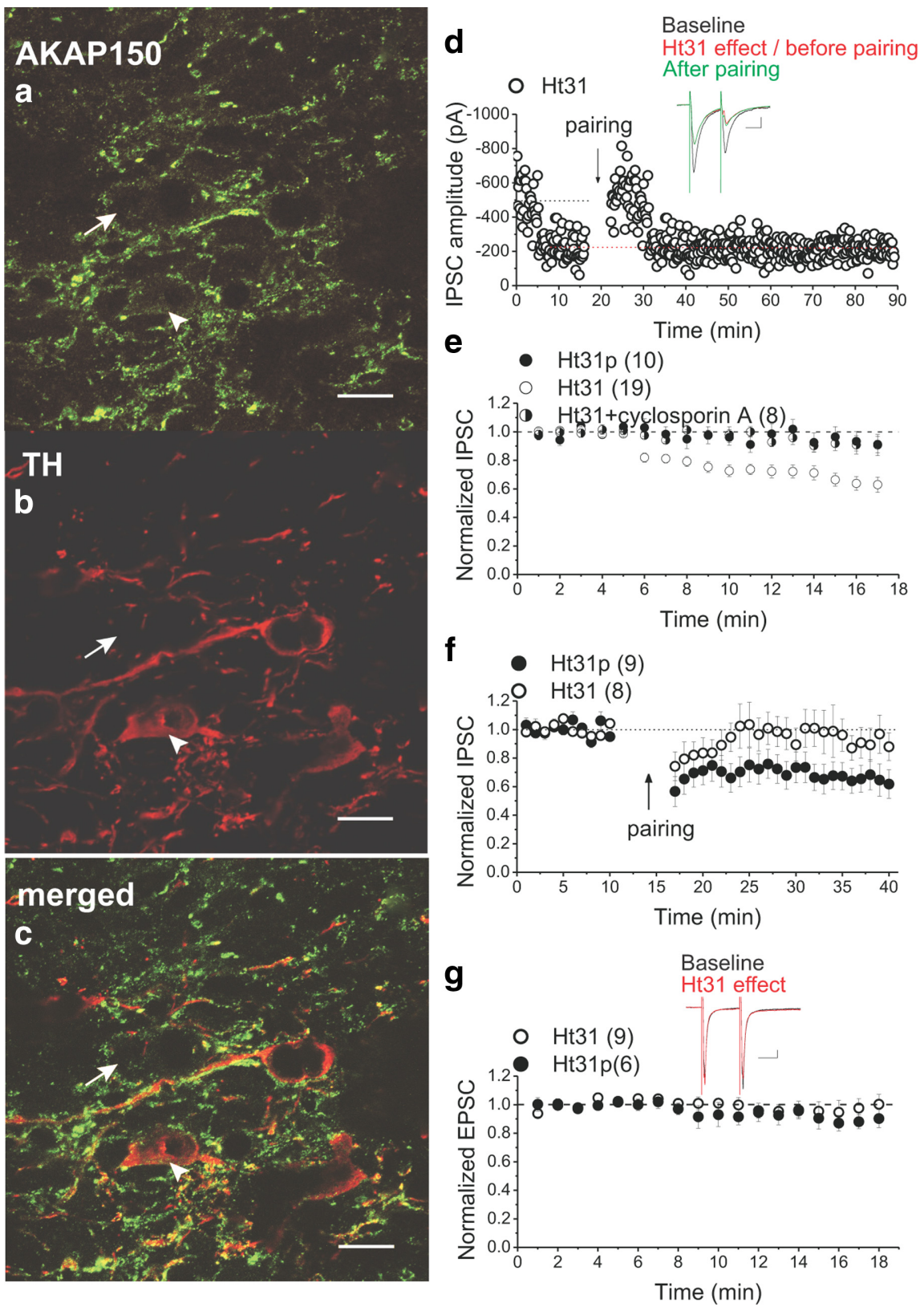

Figure 5. DA neurons of the VTA express endogenous AKAP150, and the disruption of PKA-AKAP150 selectively induces the CaN-dependent $L_{T D} D_{G A B A}$. An example of one brain section stained with antibodies to AKAP150 (green) (a), TH (red) (b), and merged from $\boldsymbol{a}$ and $\boldsymbol{b}(\boldsymbol{c})$, which shows the expression of AKAP150 in TH ${ }^{+}$neurons in the VTA. Scale bar, $10 \mu \mathrm{m}$. The arrowhead shows a VTA DA neuron with AKAP150 immunoreactivity, and the arrow shows a VTA non-DA neuron with AKAP150 immunoreactivity. $\boldsymbol{d}$, Single experiment illustrating the effect of intra-pipette $\mathrm{Ht} 31$ on basal synaptic transmission and the induction of pairing-induced $\mathrm{LTD}_{\mathrm{GABA}}$ in the Ht31-loaded cell (only the last $5 \mathrm{~min}$ of the baseline responses before the emergence of the Ht31-induced depression is shown in this sample experiment). Inset, Averaged IPSCs before (black) or the peak response of Ht31 (red) or 25 min after pairing (green). Calibration: 50 pA, 25 ms. e, Averaged experiments with intra-pipette $1 \mu \mathrm{m} \mathrm{Ht} 31$ (open symbols) or intra-pipette of $1 \mu \mathrm{m} \mathrm{Ht} 31 \mathrm{p}$ (filled symbols) or intra-pipette $1 \mu \mathrm{m}$ Ht31 plus $1 \mu \mathrm{m}$ cyclosporine A (half-filled symbols). Ht31 induces a rapid rundown of IPSCs that is blocked by cyclosporin A treatment ( $\mathrm{Ht} 31 \mathrm{p}$ cells, $97 \pm 8 \%$ of the first 5 min baseline values, $F_{(3.0,21.0)}=1.187, p=0.339 ; \mathrm{Ht} 31$ cells, $58 \pm 6 \%$ of the first 5 min baseline values, $F_{(2.2,36.6)}=37.871, p<0.0001 ; \mathrm{Ht} 31$ plus cyclosporine $\mathrm{A}, 92 \pm 2 \%$ of the first 5 min baseline values, $\left.F_{(2.1,10.4)}=2.044, p=0.178\right)$. $\boldsymbol{f}$, Averaged LTD induction experiments with control Ht31p peptide (filled symbols) or intra-pipette $\mathrm{Ht} 31$ (open symbols). Ht31-induced depression prevents pairing-induced LTD $_{\text {GABA }}$ (Ht31p cells, $65 \pm 2 \%$ of pre-pairing values, $F_{(3.4,26.9)}=8.334, p<0.0001$; Ht31 cells, $90 \pm 4 \%$ of pre-pairing values, $F_{(3.6,21.4)}=$ $1.112, p=0.373$ ). $g$, Averaged experiments with intra-pipette $1 \mu \mathrm{m} \mathrm{Ht} 31$ (open symbols) or intra-pipette $1 \mu \mathrm{m} \mathrm{Ht} 31 \mathrm{p}$ (filled symbols) on AMPAR-mediated EPSCs of $I_{\mathrm{h}}{ }^{(+)}$neurons. Ht31 does not affect basal glutamatergic transmission mediated by AMPARs (Ht31p, $90 \pm 3 \%$ of the first 5 min baseline values, $F_{(1.9,9.6)}=3.391, p=0.078$; Ht31 cells, $74 \pm$ $14 \%$ of the first $5 \mathrm{~min}$ baseline values, $\left.F_{(1.8,12.6)}=0.548, p=0.574\right)$. 

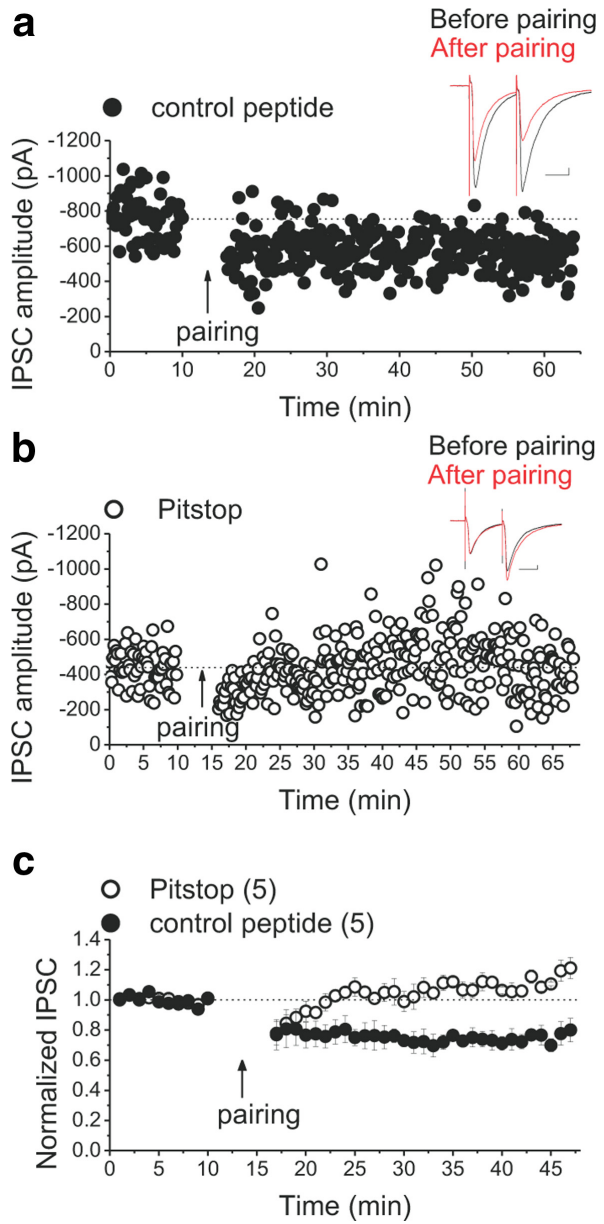

Figure 6. Clathrin-mediated internalization of $G_{A B A}$ Rs underlies the expression of LT$D_{G A B A} \cdot \boldsymbol{a}, \boldsymbol{b}$, Single experiments showing induction of $\mathrm{LTD}_{\mathrm{GABA}}$ in cells loaded with Pitstop2 control peptide (filled symbols) or Pitstop2 (open symbols). Insets, Averaged IPSCs before (black) and 25 min after (red) pairing. Calibration: 50 pA, 25 ms. c, Averaged LTD experiments with Pitstop2 control peptide (filled symbols) or Pitstop2 (open symbols). Pitstop2 blocks pairing-induced $\mathrm{LTD}_{\mathrm{GABA}}$, whereas control peptide did not affect the induction of $\mathrm{LTD}_{\mathrm{GABA}}$ (control peptide cells, $76 \pm 3 \%$ of pre-pairing values, $F_{(5.9,17.88)}=10.149, p<0.0001$; Pitstop cells, $115 \pm 5 \%$ of pre-pairing values, $\left.F_{(1.39,4.17)}=5.129, p=0.080\right)$.

Postsynaptic loading of cells with $50 \mu \mathrm{M}$ Pitstop2 prevented $\mathrm{LTD}_{\mathrm{GABA}}$, whereas cells loaded with $50 \mu \mathrm{M}$ Pitstop-control peptide still exhibited $\mathrm{LTD}_{\mathrm{GABA}}$ in response to the synaptic stimulation (Fig. 6).

In summary, we have demonstrated that the induction of LTD ${ }_{\text {GABA }}$ results from $\mathrm{D}_{2} \mathrm{R}$ activation inhibiting PKA, coupled with depolarization- and $\mathrm{IP}_{3} \mathrm{R}$-induced $\mathrm{Ca}^{2+}$ release from internal stores, leading to AKAP-mediated activation of $\mathrm{CaN}$ and $\mathrm{CaN}$-induced internalization of $\mathrm{GABA}_{\mathrm{A}}$ Rs in VTA DA neurons through a clathrin-mediated mechanism.

\section{Discussion}

We have identified a novel signaling cascade involving PKA, $\mathrm{IP}_{3} \mathrm{R}, \mathrm{Ca}^{2+}$, AKAP, and $\mathrm{CaN}$ downstream to $\mathrm{D}_{2} \mathrm{R}$ stimulation that selectively regulates the strength of $\mathrm{GABA}_{\mathrm{A}} \mathrm{R}$ synapses and $\mathrm{GABA}_{\mathrm{A}} \mathrm{R}$ trafficking in VTA DA neurons and provides one expression mechanism for $\mathrm{LTD}_{\mathrm{GABA}}$.

Our findings are consistent with the hypothesis that postsynaptic mechanisms are involved in induction and expression of $\mathrm{LTD}_{\mathrm{GABA}}$. Postsynaptic disruption of G-protein signaling prevented $\mathrm{LTD}_{\mathrm{GABA}}$, confirming that $\mathrm{D}_{2}$ autoreceptors are essential in the induction of $\mathrm{LTD}_{\mathrm{GABA}}$. We further elucidated that blockade of group I mGluRs and $\mathrm{GABA}_{\mathrm{B}}$ Rs did not impair $\mathrm{LTD}_{\mathrm{GABA}}$, excluding the possible roles of these GPCRs in LTD $_{\mathrm{GABA}}$. These findings do not rule out a role for other GPCRs that may be involved in the induction of $\mathrm{LTD}_{\mathrm{GABA}}$ and also converge on the AKAP-CaN complex to induce $\mathrm{LTD}_{\mathrm{GABA}}$ with/without involving the PKA signaling pathway.

Because the intracellular inclusion of BAPTA, a fast $\mathrm{Ca}^{2+}$ chelator, did not block $\mathrm{LTD}_{\mathrm{GABA}}$, a global increase in intracellular $\mathrm{Ca}^{2+}$ concentration is not necessary, but insensitivity to intrapipette BAPTA does not rule out local increases in intracellular $\mathrm{Ca}^{2+}$ concentrations close to the point of $\mathrm{Ca}^{2+}$ entry/release. Therefore, a local postsynaptic $\mathrm{Ca}^{2+}$ signaling near the $\mathrm{Ca}^{2+}$ entry site might be sufficient to involve the signaling complex for triggering $\mathrm{LTD}_{\mathrm{GABA}}$. In fact, it has been argued that the dissociation constant of BAPTA for $\mathrm{Ca}^{2+}$ makes it an inefficient $\mathrm{Ca}^{2+}$ chelator at relatively low intracellular $\mathrm{Ca}^{+2}$ levels. Therefore, it is likely that $\mathrm{CaN}$ is active at low levels of $\mathrm{Ca}^{2+}$ under resting basal conditions (Wang and Kelly, 1997). Moreover, it has been shown that, in the presence of BAPTA, $\mathrm{Ca}^{2+}$ signals might still occur near the $\mathrm{Ca}^{2+}$ source (Issa and Hudspeth, 1996; Nieves-Cintrón et al., 2008). A similar scenario has been reported in arterial smooth muscle cells in which the AKAP150/CaN /NFATc3 signaling is activated by a local PKC-dependent $\mathrm{Ca}^{2+}$ signaling in cells loaded with BAPTA (Nieves-Cintrón et al., 2008). Postsynaptic depolarization is also needed to trigger $\mathrm{LTD}_{\mathrm{GABA}}$, suggesting that some voltage-dependent processes facilitate the induction of $\mathrm{LTD}_{\mathrm{GABA}}$. We observed that the blockade of L-type VGCCs did not affect $\mathrm{LTD}_{\mathrm{GABA}}$, suggesting that the influx of extracellular $\mathrm{Ca}^{2+}$ via these voltage-dependent channels is not needed for $\mathrm{LTD}_{\mathrm{GABA}}$. Another source of $\mathrm{Ca}^{2+}$ entry to cytosol is from internal stores, which release $\mathrm{Ca}^{2+}$ through channels such as $\mathrm{IP}_{3} \mathrm{Rs}$ located on the endoplasmic reticulum (ER) membranes. We also found that the $\mathrm{IP}_{3} \mathrm{R}$-mediated $\mathrm{Ca}^{2+}$ release underlie the induction of $\mathrm{LTD}_{\mathrm{GABA}}$ because intra-pipette application of heparin, an $\mathrm{IP}_{3} \mathrm{R}$ blocker, completely abolished LTD. Given that $\mathrm{D}_{2} \mathrm{Rs}$ have direct effects on various voltage-gated ion channels $\left(\mathrm{Na}^{+}, \mathrm{K}^{+}\right.$, and $\mathrm{Ca}^{2+}$ channels) or through inhibition of the cAMP-PKA pathway (Neve et al., 2004), it is likely that $D_{2} R$ activation may involve some of voltage-dependent ion channels located on ER to facilitate the $\mathrm{IP}_{3} \mathrm{R}$-mediated $\mathrm{Ca}^{2+}$ release. In fact, it has been suggested that neurons may possess such voltagedependent mechanisms for intracellular $\mathrm{Ca}^{2+}$ release that could act through G-protein, phospholipase C (PLC), and $\mathrm{IP}_{3} \mathrm{R}$ activation (Ryglewski et al., 2007). Consistent with our findings, it has been shown that $\mathrm{D}_{2} \mathrm{R}$ activation can increase the cytosolic levels of $\mathrm{Ca}^{2+}$ via PLC/PKA-IP ${ }_{3} \mathrm{R}-\mathrm{CaN}$ signaling cascades (HernandezLopez et al., 2000; Hu et al., 2005). Moreover, phosphorylation of $\mathrm{IP}_{3} \mathrm{Rs}$ by PKA seems to decrease its ability to release $\mathrm{Ca}^{2+}$ (Supattapone et al., 1988; Quinton and Dean, 1992). Whether the $\mathrm{D}_{2} \mathrm{R}-\mathrm{IP}_{3} \mathrm{R}$-mediated local increase in intracellular $\mathrm{Ca}^{2+}$ underlying $\mathrm{LTD}_{\mathrm{GABA}}$ involves only PKA or also engages PLC remains to be elucidated.

Our next experiments confirmed that the expression of $\mathrm{LTD}_{\mathrm{GABA}}$ is dependent on $\mathrm{CaN}$; two different CaN inhibitors prevented $\mathrm{LTD}_{\mathrm{GABA}}$ without affecting the basal synaptic transmission. Similarly, postsynaptic CaN plays an important role in LTD of GABAergic synapses in neurons of deep cerebellar nuclei and in CA1 neurons of the hippocampus (Morishita and Sastry, 1996; Lu et al., 2000; Wang et al., 2003). In the hippocampus, CaN-mediated dephosphorylation of the $\gamma 2$ subunit of $\mathrm{GABA}_{\mathrm{A}} \mathrm{Rs}$ increases $\mathrm{GABA}_{\mathrm{A}} \mathrm{R}$ diffusion away from synapses, thereby resulting in less confinement of postsynaptic receptors at 
GABAergic synapses and LTD expression (Wang et al., 2003). Our experiments with Pitstop2 now clearly show that clathrinmediated endocytosis of $\mathrm{GABA}_{\mathrm{A}}$ Rs underlies the $\mathrm{CaN}$-dependent $\mathrm{LTD}_{\mathrm{GABA}}$. However, our results do not exclude a role for other PPs in GABA $\mathrm{A}_{\mathrm{A}} \mathrm{R}$ trafficking and LTD because dephosphorylation of $\beta$ subunits by $\mathrm{PP} 1 \alpha$ and $\mathrm{PP} 2 \mathrm{~A}$ has also been shown to trigger clathrin-mediated $\mathrm{GABA}_{\mathrm{A}} \mathrm{R}$ internalization (Luscher et al., 2011).

Postsynaptic inhibition of the activity of PKA is sufficient to suppress glutamatergic transmission and occlude an excitatory LTD that is CaN dependent (Kameyama et al., 1998; Tavalin et al., 2002; Snyder et al., 2005). Moreover, the regulation of $\mathrm{GABA}_{\mathrm{A}}$ Rs by PKA activity has been widely observed (Brandon et al., 2002). It was very likely that $D_{2} R$ stimulation leads to inhibition of the G-protein-coupled PKA intracellular pathway to allow $\mathrm{CaN}$ activity. Consistent with this hypothesis, we found that application of a $\mathrm{D}_{2} \mathrm{R}$ agonist (quinpirole) or postsynaptic inclusion of a cell-impermeable PKA inhibitor $\left(\mathrm{PKI}_{(6-22)}\right)$ both induced a chemical form of CaN-dependent LTD that shares a common expression mechanism with $\mathrm{LTD}_{\mathrm{GABA}}$. Moreover, PKI-induced depression occluded any additional quinpirole-induced depression, confirming that postsynaptic $\mathrm{D}_{2} \mathrm{R}$ activation acts via PKA inhibition to trigger LTD. These findings suggest that the basal PKA activity is sufficient to maintain basal GABAergic transmission, and the basal effect of CaN on GABAergic transmission becomes unmasked only in the absence of PKA activity (in this case, $\mathrm{D}_{2} \mathrm{R}$ stimulation).

How could $\mathrm{D}_{2} \mathrm{R}$ stimulation and PKA inhibition favor activation of CaN? Several recent studies have shown that LTD and endocytosis of AMPARs at excitatory synapses of the hippocampus requires the binding of endogenous AKAP to CaN and PKA (Kameyama et al., 1998; Tavalin et al., 2002; Snyder et al., 2005; Bhattacharyya et al., 2009; Jurado et al., 2010). In fact, AKAPs can interact directly with $\mathrm{CaN}$ and PKC in addition to PKA at these synapses (Sanderson and Dell'Acqua, 2011). The interaction of

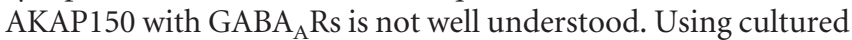
neurons, Brandon et al. (2003) have reported a direct interaction between AKAP150 and the $\mathrm{GABA}_{\mathrm{A}} \mathrm{R} \beta 1$ and $\beta 3$ subunits. The PKA phosphorylation of the $\mathrm{GABA}_{\mathrm{A}} \mathrm{R} \beta 3$ subunits was also reported to be AKAP150-dependent. Another group has argued that the interaction between AKAP150 and the $\mathrm{GABA}_{\mathrm{A}} \mathrm{R} \beta 2 / 3$ subunits in the CA1 hippocampal neurons occurs predominantly in the Golgi apparatus rather than at inhibitory synapses in which $\mathrm{GABA}_{\mathrm{A}} \mathrm{R}$-associated protein, a $\mathrm{GABA}_{\mathrm{A}} \mathrm{R}$-interacting protein important for $\mathrm{GABA}_{\mathrm{A}} \mathrm{R}$ trafficking, is also present (Lilly et al., 2005). Our immunohistochemical studies strongly suggest that endogenous AKAP is expressed in VTA DA neurons. However, it is still unknown whether a direct interaction between $G_{A B A} R$ subunits and AKAP150 take place at these synapses and whether the targeting of $\mathrm{CaN}$ to $\mathrm{GABA}_{\mathrm{A}} \mathrm{Rs}$ is AKAP150 dependent or also requires other postsynaptic scaffold proteins (Vithlani et al., 2011). If the basal effect of an anchored PKA to AKAP150 is the main determinant of the strength of GABAergic transmission, then the counteracting effect of $\mathrm{CaN}$ on GABAergic transmission will only be favored once the PKA-AKAP association is disrupted. Using the AKAP inhibitor peptide Ht31, we demonstrated that, similar to $\mathrm{D}_{2} \mathrm{R}$ stimulation and postsynaptic inhibition of PKA, postsynaptic disruption of PKA binding from AKAP induces a form of chemical LTD that occludes stimulusinduced $\mathrm{LTD}_{\mathrm{GABA}}$. Because of the specific targeting of AKAP150 by $\mathrm{Ht} 31, \mathrm{Ht} 31$ treatment seemed to have a more robust depressing effect on GABAergic transmission than treatments acting more distally to AKAP, presenting the possibility of a floor effect in the Ht31 occlusion experiments. However, similar to quinpirole- and PKI-induced rundown and $\mathrm{LTD}_{\mathrm{GABA}}$, the Ht31 rundown was postsynaptic and also $\mathrm{CaN}$ dependent. In fact, the magnitudes of rundown induced by $\mathrm{PKI}$, quinpirole, $\mathrm{Ht} 31$, and LTD $_{\text {GABA }}$ were not significantly different, and the concentrations of drugs used in this study were selected to give a level of receptor/ target occupancy that should be in the submaximal range. Remarkably, the effect of $\mathrm{Ht} 31$ was selective to $\mathrm{GABA}_{\mathrm{A}} \mathrm{R}$ synapses because AMPAR-mediated glutamatergic transmission was unaffected by $\mathrm{Ht} 31$ treatment. Consistent with this finding, postsynaptic stimulation rather than inhibition of PKA activity is suggested to be necessary for induction of glutamatergic LTD in VTA DA neurons (Gutlerner et al., 2002).

We conclude that the PKA-anchored AKAP tonically regulates the strength of $\mathrm{GABA}_{\mathrm{A}} \mathrm{R}$-mediated transmission and counteracts the basal effects of $\mathrm{CaN}$ on $\mathrm{GABA}_{\mathrm{A}}$ synapses in VTA DA neurons. Once LTD is induced by $\mathrm{D}_{2} \mathrm{R}$ activation, the basal PKAAKAP activity is inhibited, allowing $\mathrm{CaN}$ to become dissociated from the AKAP complex and becomes active to dephosphorylate $\mathrm{GABA}_{\mathrm{A}} \mathrm{Rs}$ and promote $\mathrm{GABA}_{\mathrm{A}} \mathrm{R}$ internalization that will ultimately result in $\mathrm{LTD}_{\mathrm{GABA}}$.

DA signaling enables reward-related learning through its role in shaping synaptic plasticity and DA cell excitability(Wise, 2008). Therefore, induction of a transient $\mathrm{LTD}_{\mathrm{GABA}}$ by local release of DA and $\mathrm{D}_{2} \mathrm{R}$ activation of DA neurons in response to natural rewarding stimuli may serve as a physiological mechanism to decrease the GABAergic inhibitory tone on DA neurons. The resulting increase in DA cell excitability might contribute to the formation of reward-related associative memory. Additionally, addictive drugs increase somatodendritic release of DA (Bradberry and Roth, 1989; Klitenick et al., 1992; Campbell et al., 1996); therefore, it is likely that part of the increased DA cell excitability and DA release in VTA target areas induced by addictive drugs is attributable to an induction of a permanent $\mathrm{LTD}_{\mathrm{GABA}}$ through $\mathrm{D}_{2} \mathrm{R}$ stimulation, leading to reduced PKA regulation of AKAP150-anchored CaN activity in the VTA DA neurons. It will be of particular interest to determine whether selective manipulation of GABAergic plasticity through AKAPdependent signaling in the VTA modulates natural and druginduced reward. The input specificity of AKAP signaling in VTA DA neurons may provide an important means by which GABAergic inputs onto DA neurons could be selectively manipulated with minimal effects on other inputs. Therefore, pharmacological or genetic targeting of AKAP150 in the VTA DA signaling may present novel and more selective therapeutic interventions to overcome drug addiction.

\section{References}

Adamantidis AR, Tsai HC, Boutrel B, Zhang F, Stuber GD, Budygin EA, Touriño C, Bonci A, Deisseroth K, de Lecea L (2011) Optogenetic interrogation of dopaminergic modulation of the multiple phases of rewardseeking behavior. J Neurosci 31:10829-10835. CrossRef Medline

Adermark L, Lovinger DM (2007) Combined activation of L-type $\mathrm{Ca}^{2+}$ channels and synaptic transmission is sufficient to induce striatal longterm depression. J Neurosci 27:6781-6787. CrossRef Medline

Bellone C, Lüscher C (2005) mGluRs induce a long-term depression in the ventral tegmental area that involves a switch of the subunit composition of AMPA receptors. Eur J Neurosci 21:1280-1288. CrossRef Medline

Bhattacharyya S, Biou V, Xu W, Schlüter O, Malenka RC (2009) A critical role for PSD-95/AKAP interactions in endocytosis of synaptic AMPA receptors. Nat Neurosci 12:172-181. CrossRef Medline

Biala G, Betancur C, Mansuy IM, Giros B (2005) The reinforcing effects of chronic $\mathrm{D}$-amphetamine and morphine are impaired in a line of memorydeficient mice overexpressing calcineurin. Eur J Neurosci 21:3089-3096. CrossRef Medline 
Bradberry CW, Roth RH (1989) Cocaine increases extracellular dopamine in rat nucleus accumbens and ventral tegmental area as shown by in vivo microdialysis. Neurosci Lett 103:97-102. CrossRef Medline

Brandon N, Jovanovic J, Moss S (2002) Multiple roles of protein kinases in the modulation of gamma-aminobutyric $\operatorname{acid}(\mathrm{A})$ receptor function and cell surface expression. Pharmacol Ther 94:113-122. CrossRef Medline

Brandon NJ, Jovanovic JN, Colledge M, Kittler JT, Brandon JM, Scott JD, Moss SJ (2003) A-kinase anchoring protein 79/150 facilitates the phosphorylation of GABA(A) receptors by cAMP-dependent protein kinase via selective interaction with receptor beta subunits. Mol Cell Neurosci 22:87-97. CrossRef Medline

Cameron DL, Williams JT (1994) Cocaine inhibits GABA release in the VTA through endogenous 5-HT. J Neurosci 14:6763-6767. Medline

Campbell AD, Kohl RR, McBride WJ (1996) Serotonin-3 receptor and ethanol-stimulated somatodendritic dopamine release. Alcohol 13: 569-574. CrossRef Medline

Castillo PE, Chiu CQ, Carroll RC (2011) Long-term plasticity at inhibitory synapses. Curr Opin Neurobiol 21:328-338. CrossRef Medline

Collingridge GL, Peineau S, Howland JG, Wang YT (2010) Long-term depression in the CNS. Nat Rev Neurosci 11:459-473. CrossRef Medline

Dacher M, Nugent FS (2011a) Opiates and plasticity. Neuropharmacology 61:1088-1096. CrossRef Medline

Dacher M, Nugent FS (2011b) Morphine-induced modulation of LTD at GABAergic synapses in the ventral tegmental area. Neuropharmacology 61:1166-1171. CrossRef Medline

Di Chiara G, Imperato A (1988) Drugs abused by humans preferentially increase synaptic dopamine concentrations in the mesolimbic system of freely moving rats. Proc Natl Acad Sci U S A 85:5274-5278. CrossRef Medline

Fiorillo CD, Williams JT (1998) Glutamate mediates an inhibitory postsynaptic potential in dopamine neurons. Nature 394:78-82. CrossRef Medline

Ford CP, Mark GP, Williams JT (2006) Properties and opioid inhibition of mesolimbic dopamine neurons vary according to target location. J Neurosci 26:2788-2797. CrossRef Medline

Glantz SB, Amat JA, Rubin CS (1992) cAMP signaling in neurons: patterns of neuronal expression and intracellular localization for a novel protein, AKAP 150, that anchors the regulatory subunit of cAMP-dependent protein kinase II beta. Mol Biol Cell 3:1215-1228. Medline

Greengard P (2001) The neurobiology of dopamine signaling. Biosci Rep 21:247-269. CrossRef Medline

Gutlerner JL, Penick EC, Snyder EM, Kauer JA (2002) Novel protein kinase A-dependent long-term depression of excitatory synapses. Neuron 36: 921-931. CrossRef Medline

Hernandez-Lopez S, Tkatch T, Perez-Garci E, Galarraga E, Bargas J, Hamm $\mathrm{H}$, Surmeier DJ (2000) $\mathrm{D}_{2}$ dopamine receptors in striatal medium spiny neurons reduce $\mathrm{L}$-type $\mathrm{Ca}^{2+}$ currents and excitability via a novel PLC $\beta 1$ $\mathrm{IP}_{3}$-calcineurin-signaling cascade. J Neurosci 20:8987-8995. Medline

Horne EA, Dell'Acqua ML (2007) Phospholipase C is required for changes in postsynaptic structure and function associated with NMDA receptordependent long-term depression. J Neurosci 27:3523-3534. CrossRef Medline

Hu XT, Dong Y, Zhang XF, White FJ (2005) Dopamine $\mathrm{D}_{2}$ receptoractivated $\mathrm{Ca}^{2+}$ signaling modulates voltage-sensitive sodium currents in rat nucleus accumbens neurons. J Neurophysiol 93:1406-1417. CrossRef Medline

Issa NP, Hudspeth AJ (1996) The entry and clearance of $\mathrm{Ca}^{2+}$ at individual presynaptic active zones of hair cells from the bullfrog's sacculus. Proc Natl Acad Sci U S A 93:9527-9532. CrossRef Medline

Johnson SW, North RA (1992) Two types of neurone in the rat ventral tegmental area and their synaptic inputs. J Physiol 450:455-468. Medline

Jones S, Kornblum JL, Kauer JA (2000) Amphetamine blocks long-term synaptic depression in the ventral tegmental area. J Neurosci 20:55755580. Medline

Jurado S, Biou V, Malenka RC (2010) A calcineurin/AKAP complex is required for NMDA receptor-dependent long-term depression. Nat Neurosci 13:1053-1055. CrossRef Medline

Kameyama K, Lee HK, Bear MF, Huganir RL (1998) Involvement of a postsynaptic protein kinase A substrate in the expression of homosynaptic long-term depression. Neuron 21:1163-1175. CrossRef Medline

Kamikubo Y, Tabata T, Kakizawa S, Kawakami D, Watanabe M, Ogura A, Iino M, Kano M (2007) Postsynaptic GABAB receptor signalling en- hances LTD in mouse cerebellar Purkinje cells. J Physiol 585:549-563. CrossRef Medline

Klauck TM, Faux MC, Labudda K, Langeberg LK, Jaken S, Scott JD (1996) Coordination of three signaling enzymes by AKAP79, a mammalian scaffold protein. Science 271:1589-1592. CrossRef Medline

Klitenick MA, DeWitte P, Kalivas PW (1992) Regulation of somatodendritic dopamine release in the ventral tegmental area by opioids and GABA: an in vivo microdialysis study. J Neurosci 12:2623-2632. Medline

Komatsu Y (1996) GABAB receptors, monoamine receptors, and postsynaptic inositol trisphosphate-induced $\mathrm{Ca}^{2+}$ release are involved in the induction of long-term potentiation at visual cortical inhibitory synapses. J Neurosci 16:6342-6352. Medline

Kreitzer AC, Malenka RC (2005) Dopamine modulation of state-dependent endocannabinoid release and long-term depression in the striatum. J Neurosci 25:10537-10545. CrossRef Medline

Lammel S, Hetzel A, Häckel O, Jones I, Liss B, Roeper J (2008) Unique properties of mesoprefrontal neurons within a dual mesocorticolimbic dopamine system. Neuron 57:760-773. CrossRef Medline

Lammel S, Ion DI, Roeper J, Malenka RC (2011) Projection-specific modulation of dopamine neuron synapses by aversive and rewarding stimuli. Neuron 70:855-862. CrossRef Medline

Lilly SM, Alvarez FJ, Tietz EI (2005) Synaptic and subcellular localization of A-kinase anchoring protein 150 in rat hippocampal CA1 pyramidal cells: co-localization with excitatory synaptic markers. Neuroscience 134:155-163. CrossRef Medline

Lu YM, Mansuy IM, Kandel ER, Roder J (2000) Calcineurin-mediated LTD of GABAergic inhibition underlies the increased excitability of CA1 neurons associated with LTP. Neuron 26:197-205. CrossRef Medline

Luscher B, Fuchs T, Kilpatrick CL (2011) GABA(A) receptor traffickingmediated plasticity of inhibitory synapses. Neuron 70:385-409. CrossRef Medline

Lüscher C, Huber KM (2010) Group 1 mGluR-dependent synaptic longterm depression: mechanisms and implications for circuitry and disease. Neuron 65:445-459. CrossRef Medline

Lüscher C, Malenka RC (2011) Drug-evoked synaptic plasticity in addiction: from molecular changes to circuit remodeling. Neuron 69:650-663. CrossRef Medline

Margolis EB, Lock H, Hjelmstad GO, Fields HL (2006a) The ventral tegmental area revisited: is there an electrophysiological marker for dopaminergic neurons? J Physiol 577:907-924. CrossRef Medline

Margolis EB, Lock H, Chefer VI, Shippenberg TS, Hjelmstad GO, Fields HL (2006b) Kappa opioids selectively control dopaminergic neurons projecting to the prefrontal cortex. Proc Natl Acad Sci U S A 103:2938-2942. CrossRef Medline

Morishita W, Sastry BR (1996) Postsynaptic mechanisms underlying longterm depression of GABAergic transmission in neurons of the deep cerebellar nuclei. J Neurophysiol 76:59-68. Medline

Neve KA, Seamans JK, Trantham-Davidson H (2004) Dopamine receptor signaling. J Recept Signal Transduct Res 24:165-205. CrossRef Medline

Nieves-Cintrón M, Amberg GC, Navedo MF, Molkentin JD, Santana LF (2008) The control of $\mathrm{Ca}^{2+}$ influx and NFATc3 signaling in arterial smooth muscle during hypertension. Proc Natl Acad Sci U S A 105: 15623-15628. CrossRef Medline

Nishi A, Snyder GL, Greengard P (1997) Bidirectional regulation of DARPP-32 phosphorylation by dopamine. J Neurosci 17:8147-8155. Medline

Nugent FS, Kauer JA (2008) LTP of GABAergic synapses in the ventral tegmental area and beyond. J Physiol 586:1487-1493. CrossRef Medline

Nugent FS, Penick EC, Kauer JA (2007) Opioids block long-term potentiation of inhibitory synapses. Nature 446:1086-1090. CrossRef Medline

Pan B, Hillard CJ, Liu QS (2008a) Endocannabinoid signaling mediates cocaine-induced inhibitory synaptic plasticity in midbrain dopamine neurons. J Neurosci 28:1385-1397. CrossRef Medline

Pan B, Hillard CJ, Liu QS (2008b) $\mathrm{D}_{2}$ dopamine receptor activation facilitates endocannabinoid-mediated long-term synaptic depression of GABAergic synaptic transmission in midbrain dopamine neurons via cAMP-protein kinase A signaling. J Neurosci 28:14018-14030. CrossRef Medline

Paxinos G, Watson C (2007) The rat brain in stereotaxic coordinates. San Diego: Elsevier Academic.

Quinton TM, Dean WL (1992) Cyclic AMP-dependent phosphorylation of the inositol-1,4,5-trisphosphate receptor inhibits $\mathrm{Ca}^{2+}$ release from 
platelet membranes. Biochem Biophys Res Commun 184:893-899. CrossRef Medline

Reissner KJ, Uys JD, Schwacke JH, Comte-Walters S, Rutherford-Bethard JL, Dunn TE, Blumer JB, Schey KL, Kalivas PW (2011) AKAP signaling in reinstated cocaine seeking revealed by iTRAQ proteomic analysis. J Neurosci 31:5648-5658. CrossRef Medline

Ryglewski S, Pflueger HJ, Duch C (2007) Expanding the neuron's calcium signaling repertoire: intracellular calcium release via voltage-induced PLC and IP3R activation. PLoS Biol 5:e66. CrossRef Medline

Sanderson JL, Dell'Acqua ML (2011) AKAP signaling complexes in regulation of excitatory synaptic plasticity. Neuroscientist 17:321-336. CrossRef Medline

Snyder EM, Colledge M, Crozier RA, Chen WS, Scott JD, Bear MF (2005) Role for A kinase-anchoring proteins (AKAPS) in glutamate receptor trafficking and long term synaptic depression. J Biol Chem 280:1696216968. CrossRef Medline

Supattapone S, Danoff SK, Theibert A, Joseph SK, Steiner J, Snyder SH (1988) Cyclic AMP-dependent phosphorylation of a brain inositol trisphosphate receptor decreases its release of calcium. Proc Natl Acad Sci U S A 85:8747-8750. CrossRef Medline

Tadavarty R, Rajput PS, Wong JM, Kumar U, Sastry BR (2011) Sleep-deprivation induces changes in $\mathrm{GABA}(\mathrm{B})$ and $\mathrm{mGlu}$ receptor expression and has consequences for synaptic long-term depression. PLoS One 6:e24933. CrossRef Medline
Tavalin SJ, Colledge M, Hell JW, Langeberg LK, Huganir RL, Scott JD (2002) Regulation of GluR1 by the A-kinase anchoring protein 79 (AKAP79) signaling complex shares properties with long-term depression. J Neurosci 22:3044-3051. Medline

Vithlani M, Terunuma M, Moss SJ (2011) The dynamic modulation of GABA(A) receptor trafficking and its role in regulating the plasticity of inhibitory synapses. Physiol Rev 91:1009-1022. CrossRef Medline

von Kleist L, Stahlschmidt W, Bulut H, Gromova K, Puchkov D, Robertson MJ, MacGregor KA, Tomlin N, Pechstein A, Chau N, Chircop M, Sakoff J, von Kries JP, Saenger W, Kräusslich HG, Shupliakov O, Robinson PJ, McCluskey A, Haucke V (2011) Role of the clathrin terminal domain in regulating coated pit dynamics revealed by small molecule inhibition. Cell 146:471-484. CrossRef Medline

Wang JH, Kelly PT (1997) Postsynaptic calcineurin activity downregulates synaptic transmission by weakening intracellular $\mathrm{Ca}^{2+}$ signaling mechanisms in hippocampal CA1 neurons. J Neurosci 17:46004611. Medline

Wang J, Liu S, Haditsch U, Tu W, Cochrane K, Ahmadian G, Tran L, Paw J, Wang Y, Mansuy I, Salter MM, Lu YM (2003) Interaction of calcineurin and type-A GABA receptor $\gamma 2$ subunits produces long-term depression at CA1 inhibitory synapses. J Neurosci 23:826-836. Medline

Wise RA (2008) Dopamine and reward: the anhedonia hypothesis 30 years on. Neurotox Res 14:169-183. CrossRef Medline 